\title{
Review of Passive Systems for Acid Mine Drainage Treatment
}

\author{
Jeff Skousen ${ }^{1} \cdot$ Carl E. Zipper ${ }^{2} \cdot$ Arthur Rose $^{3} \cdot$ Paul F. Ziemkiewicz $^{1} \cdot$ \\ Robert Nairn $^{4} \cdot$ Louis M. McDonald $^{1} \cdot$ Robert L. Kleinmann $^{5}$
}

Received: 1 December 2015 / Accepted: 28 August 2016 / Published online: 27 September 2016

(C) The Author(s) 2016. This article is published with open access at Springerlink.com

\begin{abstract}
When appropriately designed and maintained, passive systems can provide long-term, efficient, and effective treatment for many acid mine drainage (AMD) sources. Passive AMD treatment relies on natural processes to neutralize acidity and to oxidize or reduce and precipitate metal contaminants. Passive treatment is most suitable for small to moderate AMD discharges of appropriate chemistry, but periodic inspection and maintenance plus eventual renovation are generally required. Passive treatment technologies can be separated into biological and geochemical types. Biological passive treatment technologies generally rely on bacterial activity, and may use organic matter to stimulate microbial sulfate reduction and to adsorb contaminants; constructed wetlands, vertical flow wetlands, and bioreactors are all examples. Geochemical systems place alkalinity-generating materials such as limestone in contact with AMD (direct treatment) or with fresh water upgradient of the AMD. Most passive treatment systems employ multiple methods, often in series, to promote
\end{abstract}

Electronic supplementary material The online version of this article (doi:10.1007/s10230-016-0417-1) contains supplementary material, which is available to authorized users.

Jeff Skousen

jskousen@wvu.edu

1 West Virginia University, 1106 Agric. Sci. Bldg., Morgantown, WV 26506-6108, USA

2 Virginia Tech, Blacksburg, VA, USA

3 Pennsylvania State University, University Park, PA, USA

4 University of Oklahoma, Norman, OK, USA

5 CH2M, Pittsburgh, PA, USA acid neutralization and oxidation and precipitation of the resulting metal flocs. Before selecting an appropriate treatment technology, the AMD conditions and chemistry must be characterized. Flow, acidity and alkalinity, metal, and dissolved oxygen concentrations are critical parameters. This paper reviews the current state of passive system technology development, provides results for various system types, and provides guidance for sizing and effective operation.

Keywords Anoxic limestone drains - Bioreactors · Limestone leach beds - Low-pH Fe oxidation channels . Open limestone channels $\cdot$ Wetlands

\section{Acid Mine Drainage}

Oxidation of pyritic materials during and after mining produces sulfuric acid and metal ions. These products react with host rock and surface and groundwater to create a range of water chemistries from $\mathrm{pH} 2$ to 8 and elevated ion concentrations. Such waters have traditionally been called acid mine drainage (AMD) and alkaline mine drainage. In this paper, we use AMD when the water is acidic and state clearly in the text when the water being referred to is not acidic. When AMD enters surface water bodies, biotic impairment often occurs through direct toxicity, habitat alteration by metal precipitates, nutrient cycle alterations, or other mechanisms, and the water often becomes unsuitable for domestic, agricultural, and industrial uses. The process of pyrite oxidation and its effects on water resources have been known for centuries (Nordstrom 2011; Seal and Shanks 2008) and AMD is a worldwide concern (Younger and Wolkersdorfer 2004). Damaging effects of AMD have been described by researchers in Asia (David 2003; Wei 
et al. 2013; Yang et al. 2007), New Zealand (Trumm and Ball 2014; Winterbourn et al. 2000), Europe (Casiot et al. 2009; Gray and Delaney 2008), South America (Strosnider et al. 2011a, b), and the USA (Cherry et al. 2001; Kleinmann 1989; Soucek et al. 2000). In the eastern USA alone, $>10,000 \mathrm{~km}$ of streams and $>72,000$ ha of lakes and reservoirs were adversely affected by AMD prior to 1990 (Herlihy et al. 1990; Kleinmann 1989).

The acidity level, metal composition and concentrations of a given AMD source are controlled by the type and amount of sulfides and associated neutralizing minerals, such as calcite and dolomite. Sulfide and carbonate mineral concentrations are effective predictors of acid-producing potential of mine spoil (Sobek et al. 2000); where carbonates are absent, silica-containing minerals can provide notable amounts of alkalinity and should be accounted for (Ciccarelli et al. 2009; Miller et al. 2010). However, where there is sufficient carbonate and silicate minerals to neutralize the acidity, sulfate $\left(\mathrm{SO}_{4}{ }^{2-}\right)$ and various metal ions will still often persist in alkaline conditions. For example, even at elevated $\mathrm{pH}$, reduced metal ions such as $\mathrm{Fe}^{2+}$ and $\mathrm{Mn}^{2+}$ are much more soluble than the more oxidized $\mathrm{Fe}^{3+}$ and $\mathrm{Mn}^{4+}$.

Passive treatment of AMD was originally developed in the eastern USA's Appalachian coalfield (Hedin et al. 1994; Kleinmann 1985; Kleinmann et al. 1983; Wieder and Lang 1982), where many coal seams, especially in northern Appalachia, are associated with pyritic geologic strata. Since 1972, U.S. Federal law has required active mines to treat AMD prior to discharge. However, pre-law mining left a legacy of mine discharges that continue to impair the water quality of aquatic resources because no responsible party exists for treatment. Hence, the region's coal operators, regulatory agencies, citizens, and researchers sought low cost methods for mitigating these legacy AMD sources in order to restore impaired watersheds. Many types of passive AMD treatment technologies were developed to fit a wide variety of water conditions and many are now also being used at active mine sites.

Passive treatment is commonly considered in settings where neither the severity of AMD nor the available resources warrant active treatment that require continuous additions of alkaline chemical reagents ("active treatment") such as lime $(\mathrm{CaO})$, slaked or hydrated lime $\left(\mathrm{Ca}(\mathrm{OH})_{2}\right)$, anhydrous ammonia $\left(\mathrm{NH}_{3}\right)$, or sodium hydroxide $(\mathrm{NaOH})$ to neutralize acidity (Johnson and Hallberg 2005; Skousen et al. 1998). Active treatment requires ongoing expense for operation and maintenance, and commonly the provision of electric power. It also entails the risk of unintentional release of stored agents such as $\mathrm{NH}_{3}$ or $\mathrm{NaOH}$ that can result in harmful environmental or human exposure. Passive treatment is not subject to these problems.
Passive treatment systems rely on naturally occurring biological, geochemical, and physical processes. Biological passive treatment relies nominally on bacterial activity, such as bacterially catalyzed $\mathrm{Fe}$ and $\mathrm{Mn}$ oxidation and generation of alkalinity and metal removal via microbial sulfate reduction, along with the removal of metals via adsorption and exchange reactions with organic matter. Geochemical passive treatment relies on the reaction of water with alkalinity-generating materials such as limestone and alkaline steel slag. The systems described here have world-wide application in treating polluted water from mining operations. An earlier review by Younger et al. (2002) described the chemistry and technology of passive and active treatment, as well as AMD generation. This overview emphasizes passive treatment options and design features that can enhance their effectiveness.

\section{AMD Treatment Chemistry}

AMD production is the conversion of solid-phase acidity (sulfide minerals) to solution-phase acidity (dissolved protons and metals, primarily $\mathrm{Fe}$ and $\mathrm{Al}$ ). The low $\mathrm{pH}$ and high metal concentrations in AMD are the result of a complex set of oxidation, hydrolysis, and precipitation reactions that start with the oxidation of metal sulfide minerals. In the eastern coalfields, this is primarily pyrite; a simplified complete reaction can be written as:

$$
4 \mathrm{FeS}_{2}(\mathrm{~s})+15 \mathrm{O}_{2}+14 \mathrm{H}_{2} \mathrm{O} \rightarrow 4 \mathrm{Fe}(\mathrm{OH})_{3}(\mathrm{~s})+8 \mathrm{SO}_{4}{ }^{2-}+16 \mathrm{H}^{+}
$$

Details regarding the mechanisms and rates of pyrite oxidation can be found in Evangelou (1995) and Blowes et al. (2003), and references therein. For AMD treatment to occur, $\mathrm{pH}$ has to be increased and dissolved metals have to be removed; i.e., solution acidity decreased and solution alkalinity increased.

\section{Acidity and Alkalinity}

Acidity is a measure of a water's capacity to neutralize additions of a base (Kirby and Cravotta 2005a, b). Contributors to acidity include protons $\left(\mathrm{H}^{+}\right.$, measured as $\left.\mathrm{pH}\right)$ and metal cations with the potential to generate protons by hydrolysis. Metal hydrolysis proceeds stepwise, but the complete reaction for Fe can be written as:

$\mathrm{Fe}^{3+}+3 \mathrm{H}_{2} \mathrm{O} \leftrightarrow \mathrm{Fe}(\mathrm{OH})_{3}(\mathrm{~s})+3 \mathrm{H}^{+}$

where the dissolved metal acidity (Fe or $\mathrm{Al}$ ) has been converted completely to dissolved proton acidity and removed from the solution as a solid. Aqueous acidity can be measured directly using the standard hot peroxide method 
(APHA 1998; Kirby and Cravotta 2005b). Cravotta and Kirby (2004) urged commercial laboratories and researchers to use the Standard Methods (APHA 1998) procedure and report negative acidities. If $\mathrm{pH}$ and concentrations for dissolved metals are known, acidity can be estimated as the sum of proton acidity and the dissolved ions' mineral acidities (Hedin et al. 1994; Kirby and Cravotta 2005a). Acidity is generally expressed as a $\mathrm{CaCO}_{3}$ equivalent mass converted to concentration or loading. Alkalinity is a measure of a water's ability to neutralize acid additions (Kirby and Cravotta 2005a, b) and, like acidity, is expressed as its $\mathrm{CaCO}_{3}$ equivalent.

Alkalinity can be produced and protons neutralized by the addition of any alkaline material. The most common inorganic source of alkalinity for passive AMD treatment is limestone $\left(\mathrm{CaCO}_{3}\right)$, where the reaction is:

$\mathrm{CaCO}_{3}+\mathrm{H}^{+} \leftrightarrow \mathrm{Ca}^{+2}+\mathrm{HCO}_{3}^{-}$

Calcitic limestones are generally used in passive AMD treatment because they are more readily soluble than dolomitic (high-Mg) carbonates. Alkalinity can also be produced by microbial sulfate reduction when a labile carbon source $\left(\mathrm{CH}_{2} \mathrm{O}\right)$ is available:

$\mathrm{SO}_{4}{ }^{2-}+2 \mathrm{CH}_{2} \mathrm{O} \rightarrow \mathrm{H}_{2} \mathrm{~S}(\mathrm{~g})+2 \mathrm{HCO}_{3}{ }^{-}$

\section{Metal Removal}

Metals can be removed from AMD by precipitation and sorption. Fe and $\mathrm{Al}$ precipitate as hydroxides (Eq. 2), whereas manganese $(\mathrm{Mn})$ is removed by a combination of oxidation and precipitation.

$\mathrm{Mn}^{2+}+0.5 \mathrm{O}_{2}+\mathrm{H}_{2} \mathrm{O} \rightarrow \mathrm{MnO}_{2}(\mathrm{~s})+4 \mathrm{H}^{+}$

Mn oxidation is slow in acidic solutions but can be accelerated by bacteria and catalysis by surfaces, including auto catalysis on $\mathrm{MnO}_{2}$ (Stumm and Morgan 1996a).

Some divalent metals (e.g. Fe, $\mathrm{Zn}, \mathrm{Pb}$ ) can be removed by precipitation as sulfide minerals following microbial sulfate reduction (Eq. 4). Using $\mathrm{Fe}$ as an example, a simple, complete reaction can be written as:

$$
\mathrm{Fe}^{2+}+\mathrm{H}_{2} \mathrm{~S}(\mathrm{~g})+2 \mathrm{HCO}_{3}^{-} \rightarrow \mathrm{FeS}(\mathrm{s})+2 \mathrm{H}_{2} \mathrm{O}+2 \mathrm{CO}_{2}(\mathrm{~g})
$$

FeS in this case is mackinawite, not pyrrhotite; alternatively, greigite $\left(\mathrm{Fe}_{3} \mathrm{~S}_{4}\right)$ may form. Both are generally precursors to pyrite. Thus, precipitating metals as a sulfide is typically repeating the cycle that placed the metals in the deposit originally, reversing the oxidation reaction that liberated them.
The effect on solution-phase acidity when metals are removed by precipitation as metal hydroxides ( $\mathrm{Fe}$ and $\mathrm{Al}$ ) is straightforward and well understood (Stumm and Morgan 1996b). Metal removal by sulfide precipitation is much more complex than is suggested by Eqs. 4 and 6. Sulfate reduction reactions result in various sulfide products, but the alkalinity produced from these reduction reactions depends on the fate of the sulfide and the extent to which hydrogen sulfide or metal sulfides are produced. The reaction will reverse under oxidizing conditions, generating acidity and releasing metals all over again, so care must be taken to ensure that reducing conditions are maintained where metal sulfide precipitation has occurred.

The contribution of microbial sulfate reduction to alkalinity has been criticized for failing to account for the complexity of labile carbon sources (Lindsay et al. 2011), the potential alkalinity contributions from $\mathrm{Fe}$ reduction (Vile and Weider 1993), and incomplete consideration of the fate of $\mathrm{H}_{2} \mathrm{~S}$ (Vile and Weider 1993). The process is influenced by seasonal rate variations (i.e. reduced alkalinity generation rates in cold temperatures; Kuyucak et al. 2006), but these reduced rates can be lessened by selecting cold-hardy varieties of sulfate-reducing bacteria (Janin and Harrington 2015; Nordwick et al. 2006).

Sorption, coprecipitation, and exchange to precipitated $\mathrm{Fe}$ and $\mathrm{Mn}$, organic materials, and soil-like materials are additional mechanisms for metal removal. Sorption to organic materials is important for $\mathrm{Al}$ and divalent transition metals and $\mathrm{Pb}$, while sorption to precipitated $\mathrm{Fe}$ and $\mathrm{Mn}$ and even limestone surfaces can contribute to trace metal removal (e.g. Zachara et al. 1991).

\section{Passive AMD Treatment}

Passive treatment processes for AMD rely on natural biological, geochemical, and physical processes to improve water quality. Primary passive technologies can be broadly divided into biological systems and geochemical systems that contain inorganic materials, such as carbonates. The biological systems include aerobic and anaerobic constructed wetlands (AeWs and AnWs), vertical flow wetlands (VFWs), bioreactors (SRB), and Mn removal beds (MRBs). The geochemical systems include anoxic limestone drains (ALDs), open limestone channels (OLCs), limestone leach beds (LLBs), steel slag leach beds (SLBs), diversion wells, limestone sand, and low $\mathrm{pH} F \mathrm{Fe}$ oxidation channels. Some of the systems that we have classified as biological also use geochemical processes.

Selection of an appropriate passive system is based on water chemistry, flow rate, local topography, and site characteristics. Figure 1 (modified from Hedin et al. 1994) summarizes a strategy for selecting the appropriate type of 
passive system and Table 1 gives recommended sizing criteria. In general, AeWs are effective for removing metal precipitates from net-alkaline mine drainage. ALDs can treat acidic water with low concentrations of $\mathrm{Al}, \mathrm{Fe}^{3+}$, and dissolved oxygen (DO), while VFWs, AnWs, flushable LLBs, and OLCs can treat net-acidic water with higher concentrations of $\mathrm{Al}, \mathrm{Fe}^{3+}$, and DO. The science and technology supporting passive systems is increasing, which has improved our capacity to treat more difficult waters with appropriate designs and size.

\section{Biological Systems}

Constructed wetlands mimic their natural counterparts by creating an engineered ecosystem providing required redox, acid neutralization, and precipitate settling functions. They are often shallow excavations filled with flooded limestone gravel, soil, and organic matter to support wetland plants. Water treatment depends on dynamic biogeochemical reactions as the AMD travels through the wetland. Inorganic neutralization is a contributor if limestone is present in the substrate.

Huntsman et al. (1978) and Wieder and Lang (1982) first noted amelioration of AMD following passage through naturally-occurring Sphagnum bogs in Ohio and West Virginia. Studies by Brooks et al. (1985), Samuel et al. (1988), and Sencindiver and Bhumbla (1988) documented similar phenomena in Typha wetlands. Although evidence suggests that some wetland plants show long-term adaptation to low $\mathrm{pH}$ and high metal concentrations, AMD eventually degrades the structure and function of natural wetlands. Instead, wetland systems should be designed and constructed to mimic the natural wetland functions that are responsible for AMD treatment with the intent of providing low cost, low maintenance AMD treatment (Kleinmann 1991). The three predominant styles are AeWs, AnWs, and VFWs. Thousands of wetlands have been constructed to receive AMD from active and abandoned mines.

Passive metal retention mechanisms include: (1) metal oxidation facilitated by $\mathrm{Fe}$ and $\mathrm{Mn}$ oxidizing bacteria, hydroxide floc formation, precipitation, co-precipitation of trace metals with Fe hydroxide and Mn oxide, and capture; (2) reduction of metals and formation of metal sulfides in an organic matter layer; (3) complexation with organic matter; (4) sorption; and (5) direct uptake by living plants. Our approach herein is to define and describe each treatment type, outline the treatment mechanisms, review treatment efficiency from literature sources, and then add further commentary and summaries.

\section{Aerobic Wetlands}

AeWs are used to collect water and provide residence time for $\mathrm{Fe}$ oxidation, hydrolysis, and settling of the metal hydroxide flocs (Fig. 2). If the water is not netalkaline, limestone has to be added to create net-alkaline conditions; otherwise, the long-term efficiency and effectiveness of the AeW will be poor. AeWs are sometimes simply a shallow basin, although vegetation such as Typha (cattails) is typically planted in a loose substrate to improve wildlife habitat and aesthetics, and to promote slow flow and attachment sites for floc. Wetland vegetation also encourages more uniform flow for more effective treatment. Mn oxidation occurs more slowly than $\mathrm{Fe}$ oxidation, and is sensitive to the presence of $\mathrm{Fe}^{2+}$, which will inhibit or reverse Mn oxidation (Luan et al. 2012; Wildeman et al. 1993). Consequently in aerobic, net-alkaline water, $\mathrm{Fe}$ and $\mathrm{Mn}$ hydroxides are removed sequentially with the practical result that Mn precipitation occurs (if at all) mainly in the later stages of the system after all of the Fe has been removed. AeWs are also commonly used as a final treatment stage like settling ponds and sometimes receive treated drainage from other treatment systems to capture the remaining fine suspended precipitates (Fig. 2).

Metal removal was successful in six AeWs where the influent water $\mathrm{pH}$ was $>6$ (Skousen and Ziemkiewicz 2005). Removal rates were $10-20 \mathrm{~g} \mathrm{~m}^{-2} \mathrm{day}^{-1}$ for $\mathrm{Fe}$ and 0.5 $1.0 \mathrm{~g} \mathrm{~m}^{-2}$ day $^{-1}$ for Mn (Hedin et al. 1994). This estimate of removal efficiency remains a realistic field guideline for sizing AeWs, although it has been suggested that a better estimate of treatment effectiveness would rely on hydraulic retention time and influent acidity rather than surface area (Zipper and Skousen 2010).

AeWs remove metals by slowing the water flow and allowing for oxidation (often bacterially catalyzed). $\mathrm{As} \mathrm{Fe}^{2+}$ is oxidized, the resulting $\mathrm{Fe}^{3+}$ precipitates as ferric hydroxide in these structures as long as the $\mathrm{pH}$ is 3.5 or above. These structures also help to settle other metals that co-precipitate with the Fe.

\section{Anaerobic Wetlands}

AnWs consist of Typha and other wetland vegetation planted in deep $(>30 \mathrm{~cm})$, permeable substrates comprised of soil mixed with peat moss, spent mushroom compost, sawdust, straw/manure, hay bales, or other organic materials (Fig. 3). These materials are often underlain or mixed with limestone to aid alkalinity generation. Alkalinity is generated by carbonate dissolution and microbial sulfate reduction. Limestone will continue to react in an anaerobic environment because there is no $\mathrm{Fe}^{3+} ; \mathrm{Fe}^{2+}$ hydroxides will not form to coat the limestone surface. Reversion from reducing to oxidizing conditions will result in formation of insoluble $\mathrm{Fe}^{3+}$ hydroxide flocs, which will limit or prevent alkalinity generation and must be avoided. Several treatment mechanisms are enhanced in AnWs relative to AeWs, including 
Fig. 1 Flow chart for selecting a passive AMD treatment system based on water chemistry and flow (adapted from Hedin et al. 1994). By necessity, this flow chart does not include all possibilities. For example, Mn removal beds (MRBs) are very often used after the Fe and Al have been 1 " -->removed by the other passive treatment options and can also be used in water that is slightly acidic as long as the limestone sufficiently increases the $\mathrm{pH}$. Please consult the text for more details on all of these approaches

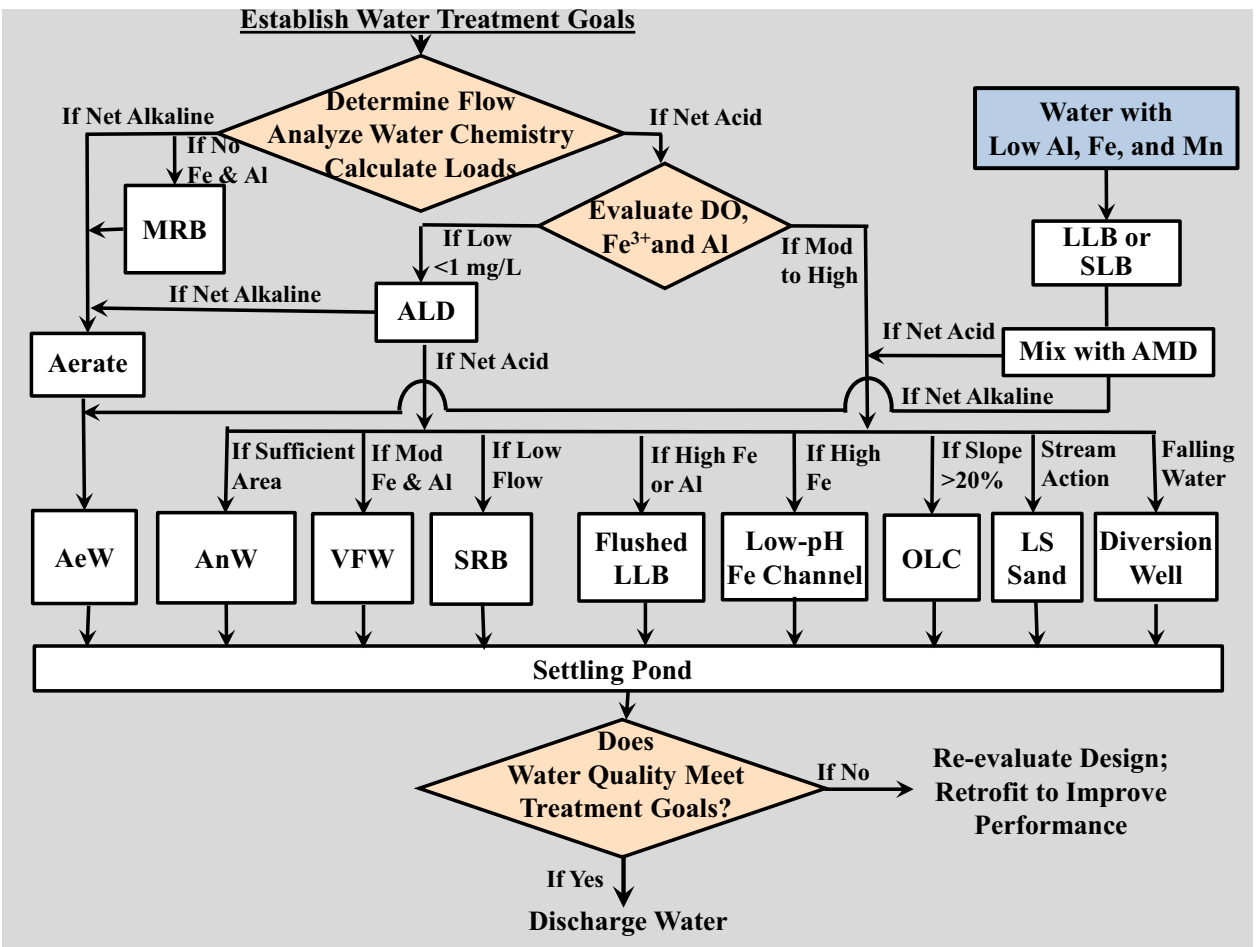

formation and precipitation of metal sulfides, microbial generation of alkalinity by sulfate reduction reactions, metal exchange and complexation reactions, and continuous formation of carbonate alkalinity due to limestone dissolution under anoxic conditions. Therefore, AnWs are suitable for the treatment of net-acidic water.

Like their aerobic counterparts, AnWs are most successful when used to treat small AMD flows of moderate acidity. Sizing criteria have been based on incoming $\mathrm{Fe}$ load $\left(10 \mathrm{~g} \mathrm{~m}^{-2}\right.$ day $^{-1}$, Hedin and Nairn 1992) or acid load (3.5 $\mathrm{g} \mathrm{m}^{-2} \mathrm{day}^{-1}$, Hedin et al. 1994). Ziemkiewicz et al. (2003) showed that 17 AnWs removed acidity at an average rate of $16.6 \mathrm{~g} \mathrm{~m}^{-2}$ day $^{-1}$.

AnWs generally work well if not overwhelmed with acid or metal loads. As the substrate is consumed or filled with metal oxyhydroxides, AnWs decline in treatment efficiency, so a maintenance schedule is needed for systems treating high metal loads. Renovation can be accomplished by removing the floc and substrate and replacing it with fresh organic material and limestone. If the materials removed from the AnWs are a mixture of limestone, organic material, and $\mathrm{Fe}$ and $\mathrm{Al}$ hydroxides, they can be used as a soil material for disturbed area reclamation when spread on the surface and allowed to dry. However, if large volumes of the floc were anaerobic, they will contain sulfides. These sulfides can oxidize and release acidity, so care should be taken to dispose of these materials in an anaerobic environment. Floc materials from metal mine drainage treatment may contain high levels of metals and therefore may not be suitable for application to land.

\section{Vertical Flow Wetlands}

VFWs were developed in the late 1980s (Hendricks 1991) and described by Duddleston et al. (1992). Kepler and McCleary (1994) advanced the term successive alkalinity producing systems (SAPS), while other researchers have referred to them as reducing and alkalinity producing systems (RAPS, Watzlaf et al. 2000a), or vertical flow ponds. In a VFW, acidic water is ponded to a depth of $1-2 \mathrm{~m}$ over 0.2 $0.6 \mathrm{~m}$ of an organic substrate, which rests on a $0.5-1 \mathrm{~m}$ layer of limestone (Fig. 4). The water's hydraulic head drives it through the organic substrate, where $\mathrm{O}_{2}$ is consumed, producing anoxic conditions. The major function of the organic layer is reduction of all $\mathrm{Fe}$ to $\mathrm{Fe}^{2+}$, which prevents coating of the underlying limestone with ferric hydroxide. Acid neutralization occurs in the organic layer by sulfate reduction and in the limestone base.

A series of perforated drainage pipes below the limestone conveys the water into an aerobic wetland or settling pond where $\mathrm{Fe}$ and $\mathrm{Mn}$ are precipitated. Initially, these systems were sized to allow 16-24 h of retention time in the limestone layer, based on the sizing criteria for ALDs (Hedin et al. 1994), but later studies of performance suggested that an areal sizing parameter was appropriate (Rose 2006). As a result, many early VFWs were not adequately sized to treat their inflow.

Reported VFW treatment efficiencies for acidity range from almost no treatment to $800 \mathrm{~g} \mathrm{~m}^{-2}$ day $^{-1}$ (Jage et al. 2000, 2001; Ji et al. 2008; Kepler and McCleary 1994; LaBar et al. 2008; Rose 2003, 2004a, b, 2006; Rose and 
Table 1 Design factors for passive treatment technologies

\begin{tabular}{|c|c|c|}
\hline System type & Design factors & References \\
\hline \multicolumn{3}{|l|}{ Biological } \\
\hline Aerobic wetland (AeW) & $10 \mathrm{~g} \mathrm{Fe} \mathrm{m}^{-2}$ day $^{-1} ; 1 \mathrm{~g} \mathrm{Mn} \mathrm{m}^{-2}$ day $^{-1}$ & $\begin{array}{l}\text { Skousen and Ziemkiewicz (2005), } \\
\text { Hedin et al. (1994) }\end{array}$ \\
\hline \multirow[t]{2}{*}{ Anaerobic wetland (AnW) } & $3.5 \mathrm{~g}_{\text {acidity }} \mathrm{m}^{-2}$ day $^{-1}$ & Skousen and Ziemkiewicz (2005) \\
\hline & $10 \mathrm{~g} \mathrm{Fe} \mathrm{m}^{-2}$ day $^{-1}$ & Hedin and Nairn (1992) \\
\hline Vertical flow wetland (VFW) & $35 \mathrm{~g}_{\text {acidity }} \mathrm{m}^{-2}$ day $^{-1}$ & $\begin{array}{l}\text { Kepler and McCleary (1997), } \\
\text { Rose (2006), Watzlaf et al. } \\
\text { (2002) }\end{array}$ \\
\hline Mn removal beds & $2-10 \mathrm{~g} \mathrm{Mn} \mathrm{m}^{-2}$ day $^{-1}$ & Rose et al. (2003a, b) \\
\hline Bioreactors & $\begin{array}{l}\text { Low flow rates; readily degradable } \\
\text { organics }\end{array}$ & $\begin{array}{l}\text { Neculita and Zagury (2008), } \\
\text { Gusek (2004) }\end{array}$ \\
\hline \multicolumn{3}{|l|}{ Geochemical } \\
\hline $\begin{array}{l}\text { Anoxic limestone drain } \\
\text { (ALD) }\end{array}$ & $\begin{array}{l}15 \mathrm{~h} \text { residence time; } 50 \mathrm{~g} \text { of acidity } \\
\mathrm{t}^{-1} \text { day }^{-1}\end{array}$ & $\begin{array}{l}\text { Watzlaf et al. (2000b), Skousen } \\
\text { and Ziemkiewicz (2005) }\end{array}$ \\
\hline $\begin{array}{l}\text { Open limestone channel } \\
\text { (OLC) }\end{array}$ & $\begin{array}{l}\text { Acid load and residence time; } 30 \mathrm{~g} \text { of } \\
\text { acidity t }^{-1} \text { day }^{-1}\end{array}$ & $\begin{array}{l}\text { Ziemkiewicz et al. (1997), Skou- } \\
\text { sen and Ziemkiewicz (2005) }\end{array}$ \\
\hline Limestone leach bed (LLB) & $\begin{array}{l}2 \mathrm{~h} \text { residence time; } 10 \mathrm{~g} \text { acidity } \\
\mathrm{t}^{-1} \text { day }^{-1}\end{array}$ & Skousen and Ziemkiewicz (2005) \\
\hline Steel-slag leach bed (SLB) & $1000 \mathrm{~g}$ acidity t $^{-1}$ day $^{-1}$ & Skousen and Ziemkiewicz (2005) \\
\hline Diversion wells & Acid load equivalence & $\begin{array}{l}\text { Arnold (1991), Ziemkiewicz and } \\
\text { Brant (1997) }\end{array}$ \\
\hline Limestone sand & $\begin{array}{l}\text { Two times acid load; applied two to } \\
\text { four times per year }\end{array}$ & $\begin{array}{l}\text { Zurbuch (1996), McClurg et al. } \\
\text { (2007) }\end{array}$ \\
\hline $\begin{array}{l}\text { Low-pH Fe oxidation } \\
\text { channels }\end{array}$ & Low $\mathrm{pH}$ water; slope for aeration & Burgos et al. (2008), Hilton 2005 \\
\hline
\end{tabular}

Dietz 2002; Rose et al. 2001; Skousen and Ziemkiewicz 2005; Watzlaf et al. 2000a). In general, performance is highest after start-up, especially if fine limestone is added to the compost layer. For VFW design purposes, a long-term acidity removal rate of $35 \mathrm{~g} \mathrm{~m}^{-2}$ day $^{-1}$ has been proposed by Rose and coworkers after an extensive review of more than 30 VFWs in the Appalachian region (Rose 2003, 2004b; Rose et al. 2004, 2007).

Watzlaf et al. (2000a) reported acidity removal rates for six VFWs ranging from 20 to $62 \mathrm{~g} \mathrm{~m}^{-2}$ day $^{-1}$ and that limestone dissolution dominated the neutralization process. An analysis of performance data for $30 \mathrm{VFWs}$ found that a few achieved removal rates $\geq 40 \mathrm{~g} \mathrm{~m}^{-2}$ day $^{-1}$ (Rose and Dietz 2002), but later evaluation indicated that $35 \mathrm{~g} \mathrm{~m}^{-2}$ day $^{-1}$ is a more accurate performance standard (Rose 2004a, 2006). Fifteen VFWs in WV decreased acidity at rates ranging from 2 to $800 \mathrm{~g} \mathrm{~m}^{-2}$ day $^{-1}$, with an average of $87 \mathrm{~g} \mathrm{~m}^{-2}$ day $^{-1}$ (Skousen and Ziemkiewicz 2005).

In addition to their use as a stand-alone treatment, VFWs can be coupled with other treatment systems to manage unique AMD situations. Water with high metal loads can be passed through multiple VFWs in series, separated by sedimentation basins for metal floc removal. Since DO concentrations are often a design limitation for other AMD passive treatment systems, a VFW can be used as pre-treatment to reduce the DO, for instance, before the water is introduced into an ALD.
An important modification to the original VFW design is the addition of $10-25 \%$ by volume of fine limestone particles into the organic substrate. With this modification, VFWs are capable of treating water with high $\mathrm{Fe}$ and $\mathrm{Al}$ concentrations. For example, installation of such a substrate at a Pennsylvania mine site caused water $\mathrm{pH}$ to increase from 2.8 to 7.4, and reduced both $\mathrm{Fe}$ and $\mathrm{Al}$ concentrations from $>36$ to $<1 \mathrm{mg} \mathrm{L}^{-1}$ (Hedin et al. 2010, 2013). Effluents were net alkaline $(\mathrm{pH}>7.4)$ for 6 years.

In 2010, the PA DEP sampled about 140 VFW systems. Of the sites built since 2004 using a sizing criterion of $35 \mathrm{~g} \mathrm{~m}^{-2}$ day $^{-1}$, at least $60 \%$ released net alkaline water (Rose 2013). Older sites, designed on retention time in the limestone, had a higher likelihood of releasing net acid effluent. Rose (2013) in his evaluation of 20 VFW systems selected from the PA DEP survey for poor performance found that $>50 \%$ did not treat the influent AMD to a net alkaline state, often due to faulty design or construction or to a lack of essential maintenance (Supplementary Table 1). Of those with correct designs, all removed $\geq 85 \%$ of influent acidity. At several of these VFW treatment sites, the receiving stream has returned to fishable status, even if the treatment system did not remove all of the acidity.

VFWs are an effective AMD treatment method when properly designed and constructed. But these systems require periodic maintenance (Hedin et al. 2013), such 


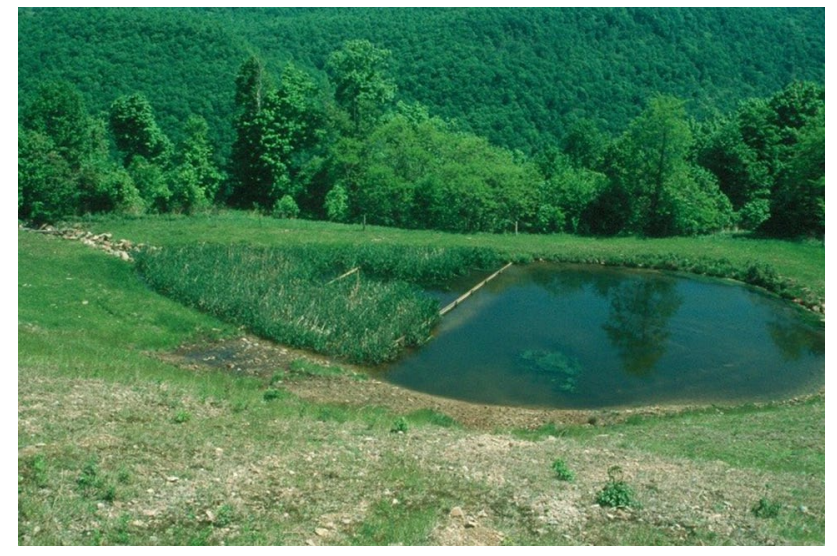

Fig. 2 Aerobic wetlands are best suited for net-alkaline water where $\mathrm{Fe}$ and $\mathrm{Mn}$ are oxidized, precipitated and captured. The metal hydroxides are collected and retained in wetland substrates. (Photo: J. Skousen)

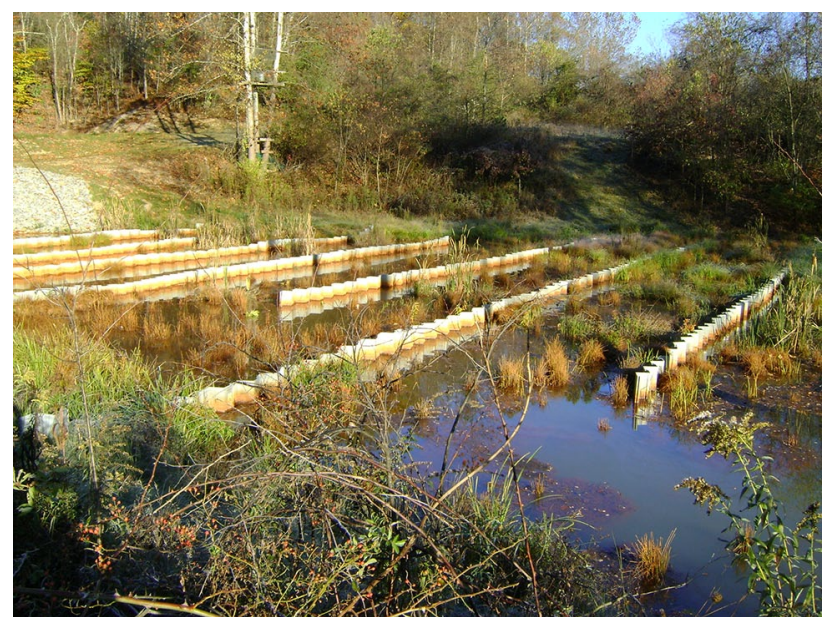

Fig. 3 Anaerobic wetlands can treat net-acidic water because microbial sulfate reduction and limestone dissolution generate alkalinity (Photos: J. Skousen)

as occasional agitation of the organic substrate to dislodge accumulated metal flocs and flushing (Fig. 5). They accomplish acid removal consistent with design standards. Flushing systems have been devised that remove more of the metal floc so that less accumulates. VFWs also need to be inspected and cleaned out when efficiency declines due to compost degradation and metal floc accumulation. Like AnWs, the substrates will need to be removed when the metal flocs build up or as the substrate becomes unreactive. Extensive data on hundreds of VFWs and other passive systems in Pennsylvania are available in the website http:// www.datashed.org.

\section{Mn Removal Beds}

$\mathrm{Mn}$ is thermodynamically insoluble at circumneutral $\mathrm{pH}$, but the abiotic rate of Mn removal in natural environments is extremely slow. However, the formation of these compounds is facilitated and catalyzed in nature by common microorganisms (Brock et al. 1994; Ghiorse 1984; Ghiorse and Ehrlich 1992; Robbins et al. 1999; Tebo et al. 2005). The bacteria are aerobic heterotrophs that use dissolved oxygen (DO) to oxidize organic matter as a source of energy. Formation of Mn precipitates by these bacteria on rock surfaces in stream channels and riverbeds has been observed at many locations (Emerson et al. 1982; Gregory and Staley 1982; Lewis 1976; Marshall 1979; Mustoe 1979; Wilson 1980).

From such experience, it has been observed that Mn can be easily removed passively in mine water with a near-neutral $\mathrm{pH}$ by simply providing an appropriate surface area for the Mn-oxidizing bacteria to populate down-gradient of the constructed wetland. The precipitation of additional $\mathrm{Mn}$ is then accelerated by the presence of these precipitates; the precipitation reaction is autocatalytic (Davies and Morgan 1989; Rose et al. 2003a, b; Tebo et al. 2005). To create the right environment for Mn removal to occur, the key requirements are to: provide an abundant amount of rock surface area as a growth substrate for the bacteria; ensure that the water contains abundant amounts of DO; if necessary, add sufficient amounts of alkalinity to increase the $\mathrm{pH}$ of the mine water to at least circumneutral levels; and, to the extent practicable, avoid the potential impacts of large storm water flow events on the retention time and stability of the channel. This approach has been successfully used at many mine sites as a polishing step following conventional passive mine water treatment (e.g. Rose et al. 2003a, b; Sikora et al. 1996; Watzlaf et al. 2004). It is increasingly common to see limestone-filled channels constructed downstream of mine water passive treatment systems that have removed virtually all of the dissolved Fe. Strictly speaking, any rock surface will do, but using limestone keeps the $\mathrm{pH}$ high enough to allow reasonably fast Mn removal.

Normally, the major obstacle to successful Mn removal using this mechanism is dissolved ferrous $\mathrm{Fe}$ because the $\mathrm{Mn}$ precipitate adsorbs the ferrous $\mathrm{Fe}$, which chemically reduces the $\mathrm{Mn}$, rendering it soluble and leaving oxidized Fe behind. Means and Rose (2005) and Rose et al. (2003a, b) studied a number of limestone beds designed for $\mathrm{Mn}$ removal. Based on these empirical observations at multiple sites and a range of conditions, $\mathrm{Mn}$ removal rates typically range from 2 to $10 \mathrm{~m}^{-2}$ day $^{-1}$ (Rose et al. 2003a, b). The rates are most likely linked to the extent of bacterial activity, as well as factors such as water depth, DO concentrations, Mn concentrations, and $\mathrm{pH}$. However, given the relatively low cost of adding additional limestone, it is generally best to make the limestone-filled channels as large as practical. Essentially all of the $\mathrm{Fe}$ and $\mathrm{Al}$ must be removed by pretreatment to avoid clogging and the $\mathrm{pH}$ must be $>6$ before $\mathrm{Mn}$ is removed; Mn removal proceeds much better at a $\mathrm{pH} \geq 7$. 


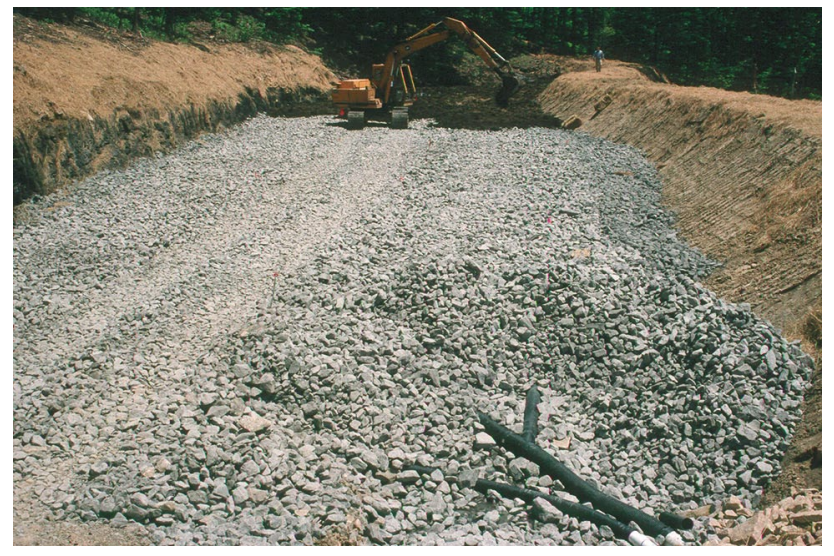

Fig. 4 Vertical flow wetlands have perforated pipes embedded in a limestone layer at the bottom of the system and overlain by organicmatter substrate. Water is ponded on the surface which drives the water through the substrate, limestone and out through the pipes. (Photos: J. Skousen)

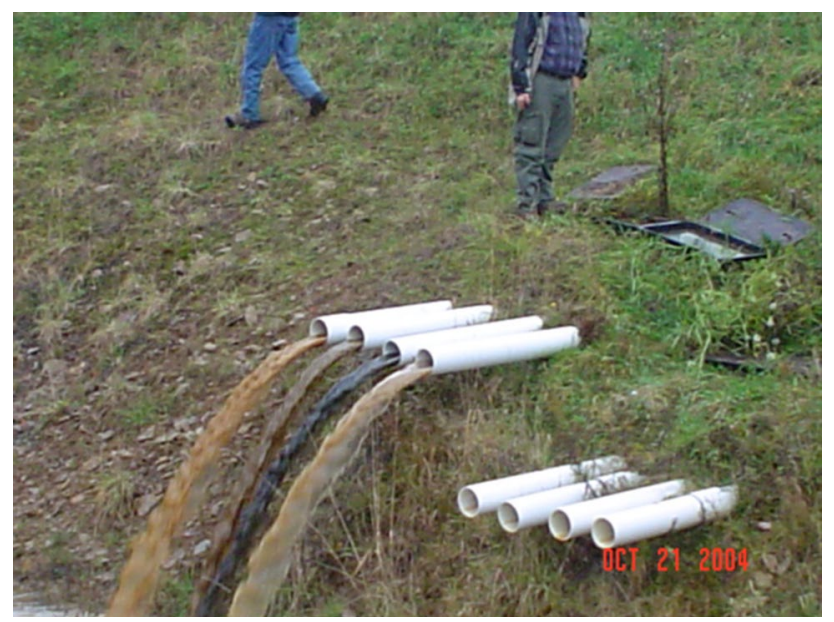

Fig. 5 Flushing systems can be placed at the outlet of VFWs to remove accumulated flocs in limestone. (Left) an operator opens a below-ground flushing valve; (right) flushed water emerges with visible flocs (Photos: J. Skousen)

These MRBs superficially resemble OLCs and LLBs, but the mechanisms and requirements are different. OLCs are generally installed where there is a relatively high slope so that Fe precipitates can be scoured from the limestone. $\mathrm{Mn}$ removal will occur in OLCs if all of the dissolved $\mathrm{Fe}$ is removed, but it is rare that dissolved $\mathrm{Fe}$ concentrations get sufficiently low. Also, scouring of precipitated $\mathrm{Mn}$ is discouraged since the precipitated Mn catalyzes additional Mn removal.

Likewise, Mn removal will also occur in LLBs if all of the dissolved $\mathrm{Fe}$ is removed, but LLBs are typically at least a meter deep; observations indicate that Mn precipitation is more rapid near the water surface, probably because of DO depletion with depth. Therefore, MRBs are typically shallow channels filled with fist-sized limestone rock. Because good air-water contact is required, the rocks should normally project out of the water.

An added advantage of MRBs is that Mn oxide minerals adsorb or incorporate substantial amounts of many trace metals. These interactions can decrease dissolved trace metal concentrations by orders of magnitude, even when only small amounts of Mn oxide is present (Jenne 1968; Tebo et al. 2004). Therefore, an MRB has been constructed at an old vanadium mine site where dissolved $\mathrm{Zn}$ and occasionally Ni exceeded permitted levels. The Fe concentrations there were naturally low and $\mathrm{Mn}$, though typically present at concentrations over $10 \mathrm{mg} / \mathrm{L}$, was not regulated because the natural background $\mathrm{Mn}$ concentrations in the area were high. Within a few months after construction, $\mathrm{Mn}$ oxidation and removal had been established and base flow trace metal concentrations were no longer in exceedance. $\mathrm{Mn}$ and trace metal removal there continues to improve.

The most common problem experienced with all limestone-lined channels is that the limestone bed can become plugged over time with silt, leaves, algae, organic matter, or other material (Rose et al. 2003a, b). Thus, monitoring and some occasional light long-term maintenance (e.g. occasional raking of the channel to remove debris) may prove to be necessary.

\section{Bioreactors}

Bioreactors, which are sometimes called sulfate-reducing bioreactors (SRB), are similar to VFWs except that organic matter is the main reactant, commonly with limestone completely mixed with the organic matter (Gusek 2004). Microbial sulfate reduction is the primary form of treatment (Neculita et al. 2007). These systems are capable of handling very acidic and metal-rich water, including mine drainage with transition and other metals. However, flow rates through these systems are slow, so they are most applicable to small flows or to relatively large systems; sometimes, multiple units are operated in parallel. Most bioreactors are used to treat metal mine drainage (e.g. Rutkowski et al. 2013), but a few have been constructed to treat acidic coal mine effluent, typically to remove selenium (Sandy and DiSante 2010). Other examples of bioreactors treating AMD from coal-mined sites include the Jennings site in PA, which plugged after 8 years but was restored by mixing and adding new reactants (Rose 2004a); the Fran site (Gusek and Schueck 2004); the Strattanville, PA, site where the system worked satisfactorily for 2 years but then failed in part because of lack of maintenance (Rose 2010); and the Reed site, which effectively treated a large flow for at least a year (Rose 2010).

Experiments on the effectiveness of a wide variety of organic materials are summarized in Table 2 and discussed further below. Commonly, relatively fine limestone or other 
calcareous materials (mussel shells, calcareous wastes, etc.) are mixed with the organic matter to help maintain the $\mathrm{pH}$ in a better range for sulfate reducers and to help neutralize the acidity. Amounts of carbonate range from a few percent to several tens of percent by volume.

Bioreactors are sometimes affected by bed compaction, which reduces permeability and promotes short circuiting. It is common to add strong particles such as gravel, coarse sand, walnut shells, and wood chips to minimize compaction and maintain permeability.

Start-up of bioreactors can be slow, while the microbial system adapts to the AMD composition and substrate. At the start, the systems may be filled with fresh water mixed with small amounts of AMD to initiate sulfate and Fe reduction; the AMD is introduced at the design flow rate as the microbial system activates. The bioreactor may be inoculated with microbes from other functioning systems to accelerate effective treatment. To date, little attention seems to have been paid to initial establishment of specific microbial species, such as those that degrade the organic matter into compounds used by sulfate-reducers, although their importance is well recognized.

A significant product of bioreactors is Fe sulfide, which removes both $\mathrm{Fe}$ and $\mathrm{S}$ from solution. FeS precipitates in the organic layer, but in some cases, the FeS is also present in the effluent and settling pond, possibly along with native $\mathrm{S}$. If these are present, these products must be kept in an anoxic environment because their oxidation will generate acidity. Bioreactor performance can be distinctly seasonal, with slower remediation in winter.

A few bioreactor systems rely on the addition of a small amount of organic supplement periodically to provide nutrients and carbon for the microorganisms (Buccambuso et al. 2007; Sobolewski 2010; Tsukamoto et al. 2004; Zamzow et al. 2006).

\section{Flushing Systems for Biological Passive Systems}

The potential for VFWs to clog with $\mathrm{Al}$ and Fe hydroxides was recognized early (Kepler and McCleary 1997) and structures to allow precipitates to be flushed from the limestone layer and pipes were installed. The early structures were manually operated with an outlet valve placed below the water level of the pond (Supplementary Fig. 1). Results from this approach were mixed. Kepler and McCleary (2003) found that flushing improved VFW effectiveness and extended useful lifetime. Watzlaf et al. (2002) found that less than $5 \%$ of the accumulated $\mathrm{Al}$ precipitate was removed during a flushing event. Designs that increase the depth of water over the organic layer to a meter or more would be expected to increase flushing effectiveness relative to shallow-water designs, but that expectation has not been tested experimentally. The decreasing effectiveness of flushed VFWs and Al accumulation on top of the limestone bed suggests that manual flushing is not a complete solution to rejuvenating VFWs when $\mathrm{Al}$ is present. Vinci and Schmidt (2001) proposed the use of automatic flushing siphons to increase flushing frequency from manual flushing, typically on a monthly schedule or to shorter intervals depending on flow rate. These siphons trigger when the pond fills to its pre-determined level. Flushing siphons have been successfully used at several sites.

A more recent flushing technology is the Agri-Drain Smart Drainage system (Agri-Drain Corp., Adair, IA). This system is programed to open a valve at certain time intervals or water levels to flush accumulated floc. Solar panels provide power so flushing can be as frequent as several times a week. This technology has been used successfully at a number of sites (Wolfe et al. 2010).

More elaborate underdrain systems have been designed to improve precipitate removal. Weaver et al. (2004) evaluated processes removing flocs during flushing, such as flow velocity, and provided design criteria for a double-layerflushing underdrain system to provide maximum flow velocity. The upper layer of pipes is near the top of the limestone layer where $\mathrm{Al}$ hydroxides are presumed to accumulate. A pilot experiment using an automatic flushing siphon flushed about $80 \%$ of the $\mathrm{Al}$ floc from a limestone bed, in contrast to the $<5 \%$ found for manual flushing at monthly intervals. Danehy et al. (2002) described systems with two layers of underdrain pipes in the limestone bed, divided into as many as eight subsystems capable of being flushed separately. This system has been used with improved results at several sites but is relatively expensive to construct.

\section{Organic Materials}

Since organic materials play such a crucial role in biological passive systems, a variety of organic materials have been evaluated (Place et al. 2006; Neculita et al. 2007; Rose 2010). Organic materials provide sorption sites for metals, and nutrients and attachment sites for microorganisms that perform essential functions, including DO consumption. A community of microorganisms is needed to degrade recalcitrant components and produce simpler organic compounds for use by the sulfate-reducing bacteria.

A wide range of organic materials have been tested for effective sulfate reduction (Table 2). These materials can be classified as: (1) easily-available substances (soluble sugars, starch, amino acids, and proteins), (2) cellulose and hemicellulose, and (3) lignin (Gibert et al. 2004). The first group are consumed relatively easily and rapidly by sulfate-reducing bacteria and their associated microbes but are commonly depleted during the first months of AMD treatment (Place et al. 2006). Cellulose is degraded slowly to simpler organic compounds by fermenting bacteria and other cellulose 
Table 2 Reported effectiveness of various organic materials for sulfate reduction (Rose 2010)

\begin{tabular}{ll}
\hline Organic substrate material & References \\
\hline
\end{tabular}

Easily-available materials — sugars, starch, proteins, oils, liquids

Edible oil substrate (EOS), mainly emulsified soybean oil, worked well in lab tests

Cheese whey added to reactors containing cow manure and pine sawdust greatly improved effectiveness

Ethanol was more satisfactory than cellulosic materials at low temperature

Methanol was effective in supporting sulfate reduction of lignite pit water

Ethanol and methanol were effective in removing $\mathrm{Fe}$ at low $\mathrm{pH}$

Glycerol-methanol waste from production of biodiesel fuel was capable of extensive sulfate reduction

Crab shell chitin was highly effective

Chitin was much more effective than lactate or compost

Chitin, hay and corn with $20-30 \%$ limestone were more effective than ethanol; chitin was very effective for Mn removal

Mussel shells were very effective in AMD treatment either alone or mixed with organic materials

Cellulose and hemicellulose materials - manures, compost

$85 \%$ pea gravel and $15 \%$ leaf compost worked well for at least 2 years

Municipal compost from wastewater treatment was poor

Sewage sludge and rye grass was better than either alone

Organic soil and ryegrass accomplished good treatment

Mushroom compost, waste paper sludge, and decayed oak chips were better than fresh oak chips and organic soil

Spent mushroom compost (mix of manure, hay, straw, corncobs, wood chips and 10-15\% limestone) worked well

Mixtures of leaf compost and poultry manure performed better than any of these materials individually

Poultry manure with $2 \%$ limestone was more effective than leaf compost and wood chips

Sheep and poultry manure were good, oak leaves were $\mathrm{OK}$, lignin poor

$80 \%$ cow manure and $20 \%$ straw performed satisfactorily in a mine-site system

$80 \%$ cow manure and $20 \%$ straw generated sulfide and precipitated metals, and increased $\mathrm{pH}$

Cow manure and rice stalks underlain by limestone in an upflow reactor removed metals until redox increased after 118 days

Cow manure and hay with $30 \%$ limestone were more effective than sawdust and wood chips

Composted cow manure mixed with ceramic pellets was effective in removing metals by adsorption

Mixtures of materials were better than pure leaf mulch, sheep manure, sewage sludge or cellulose

Decayed wood shavings, straw, manure and spent brewery grains were very effective in treating low $\mathrm{pH}$, high Fe AMD

Lignin — hay, straw, woody materials

Alfalfa hay was better than straw or timothy hay

Wood shavings, pine bark, and compost plus limestone or mussel shell mixtures worked satisfactorily in lab tests

Corn stover and walnut shells were satisfactory for $\mathrm{pH}$ 5-6 AMD

Green garden waste generated good treatment in lab tests

Maple wood sawdust with poultry manure gave good results

$90 \%$ pine sawdust and $10 \%$ hay performed poorly in two systems

Corn stover was better than alfalfa, which was better than oak, which was better than pine on sulfate reduction rates

Total $\mathrm{C}$ and cellulose/lignin ratio were useful criteria to determine sulfate reduction rates

Corn stover was more effective than hay (with limestone); both had a more diverse microbial community than with ethanol

Pine sawdust and pine chips were poor, perhaps because of toxic compounds in the pine sap
Lindow and Borden (2004, 2005)

Drury (1999)

Buccambuso et al. (2007)

Glombitza (2001)

Tsukamoto et al. (2004)

Zamzow et al. (2006)

Daubert and Brennan (2007), Newcombe and Brennan (2008)

Robinson-Lora and Brennan (2010)

Venot et al. (2008)

Trumm and Ball (2014), Uster et al. (2015)

McGregor et al. (2000)

Gibert et al. (2004)

Harris and Ragusa (2001)

Harris and Ragusa (2001)

Chang et al. (2000)

Dvorak et al. (1992)

Zagury et al. (2006)

Cocos et al. (2002)

Gibert et al. (2004)

Nordwick et al. (2006)

Zaluski et al. (2003)

Cheong et al. (1998)

Smart et al. (2008)

Willow and Cohen (2003)

Waybrant et al. (1998)

Thomas and Romanek (2002a, 2002b)

Bechard et al. (1994)

McCauley et al. (2008)

Figueroa et al. (2007)

McCullough et al. (2006)

Neculita and Zagury (2008)

Johnson and Hallberg (2005)

Place et al. (2006)

Place et al. (2006)

Prieto et al. (2008)

Zagury et al. (2006), Neculita et al. (2007) 
degraders, and the cellulose-degradation rate likely determines sulfate reduction rates in most materials. Most lignins, however, are degraded slowly, if at all. Place et al. (2006) and Zagury et al. (2006) have determined the cellulose and lignin composition in a variety of organic materials. Some researchers have found that composted materials perform less well than "fresh" organic material (e.g. manure), but composted materials work well in most cases, are less odiferous, and release less nitrates downstream.

A relatively recent innovation is the use of chitin-bearing crab shell waste as a component of the organic layer (Newcombe and Brennan 2010; Robinson-Lora and Brennan 2010). Crab shells consist of very thinly intermixed chitin, an easily biodegradable organic material, and $\mathrm{CaCO}_{3}$ accompanied by simpler organic compounds. The very fine intergrowth of these materials makes it very effective in promoting sulfate reduction and neutralization and adsorption of contaminants. The rate of acidity removal by chitin-based media was more than ten times greater than by limestoneamended compost (Robinson-Lora and Brennan 2010), but the material is relatively costly at present.

\section{Geochemical Systems}

\section{Anoxic Limestone Drains}

ALDs are buried trenches or beds filled with limestone into which anoxic AMD is introduced (Fig. 6). Based on early practical work (Brodie et al. 1991; Nairn et al. 1991; Skousen 1991; Turner and McCoy 1990), Hedin et al. (1994) provided geochemical justification for the long-term performance of ALDs. For effective operation, ALDs must be sealed to minimize $\mathrm{O}_{2}$ entry and $\mathrm{CO}_{2}$ escape. AMD emanating from underground will generally have low DO concentrations $\left(<1 \mathrm{mg} \mathrm{L}^{-1}\right)$ and elevated $\mathrm{CO}_{2}$ partial pressures $\left(\mathrm{pCO}_{2}\right)$ values $\left(>10^{-1} \mathrm{~atm}\right)$. On contact with acid water under low $\mathrm{DO}$ and high $\mathrm{pCO}_{2}$ conditions, limestone dissolves, raising $\mathrm{pH}$ and adding bicarbonate alkalinity. Under these conditions, limestone dissolution is controlled by the saturation index of calcite. Limestone does not coat or armor if $\mathrm{Fe}$ is present in the ferrous $\left(\mathrm{Fe}^{2+}\right)$ state, as ferrous hydroxide $\left(\mathrm{Fe}(\mathrm{OH})_{2}\right)$ does not form until $\mathrm{pH}>8.0$, which is higher than what is achieved in properly functioning ALDs. Appreciable concentrations of dissolved $\mathrm{Fe}^{3+}$ or $\mathrm{Al}$ will result in precipitation and coating of limestone surfaces (Watzlaf et al. 1992; Ziemkiewicz et al. 1997) or in clogging of the interstitial spaces (Faulkner and Skousen 1994; Watzlaf et al. 1994), which degrades system performance and shortens the effective lifespan (Nairn et al. 1992; Watzlaf 2000a). To minimize the risk of failure, influent AMD should contain less than $1 \mathrm{mg} \mathrm{L}^{-1}$ dissolved $\mathrm{Fe}^{+3}, \mathrm{Al}$, and $\mathrm{O}_{2}$ (Hedin et al. 1994). Since AMD often contains elevated concentrations of dissolved $\mathrm{Fe}^{3+}, \mathrm{Al}$, and $\mathrm{O}_{2}$, other passive treatment technologies to strip $\mathrm{O}_{2}$, convert $\mathrm{Fe}^{3+}$ to $\mathrm{Fe}^{2+}$, and precipitate $\mathrm{Al}^{3+}$ in a submerged organic substrate have been studied (Kepler and McCleary 1994; Skousen 1995).

ALDs were first described by Turner and McCoy (1990) in Tennessee. Brodie (1993) reported that ALDs improved the capability of wetlands to meet effluent limitations without chemical treatment. Treatment of AMD with low DO, $\mathrm{Al}$, and $\mathrm{Fe}^{3+}$ using ALDs has been found to be successful if the systems are designed, constructed, and operated correctly. Based on experiments in cubitainers and full-scale limestone drains, Cravotta and Watzlaf (2002) and Cravotta (2003) derived rates of acid neutralization for ALDs and recommended a sizing method. Mukhopadhyay et al. (2007) extended this work. Models for calcite dissolution and gypsum precipitation in ALDs have been described (Huminicki and Rimstidt 2007), including waters with $\mathrm{SO}_{4}{ }^{2-}$ concentrations above $1500 \mathrm{mg} \mathrm{L}^{-1}$. Hedin et al. $(2010,2013)$ described an ALD that has treated influent mine drainage of $\mathrm{pH} 6,36$ to $58 \mathrm{mg} \mathrm{L}^{-1}$ of acidity, $42 \mathrm{mg} \mathrm{L}^{-1}$ of $\mathrm{Fe}$, and $<1 \mathrm{mg} \mathrm{L}^{-1}$ of Al at a flow of $430 \mathrm{~L} \mathrm{~min}^{-1}$ without maintenance for 18 years. The water produced was net alkaline after Fe precipitation in settling ponds.

Skousen and Ziemkiewicz (2005) evaluated 36 ALDs and observed a wide range of acid load treatment $\left(0-130\right.$ t year $\left.^{-1}\right)$ but found no apparent relationships between ALD effectiveness and the $\mathrm{pH}$ of influent water or residence time. The average acidity removal rate was $86 \mathrm{~g} \mathrm{t}^{-1}$ day $^{-1}$ of limestone. Zipper and Skousen (2010) demonstrated that these systems' alkalinity-generating performance increased in response to increasing influent acidity and residence times. However, Hedin et al. (1994) found that treatment effectiveness decreased as calcite saturation was approached. When properly designed, ALDs perform well over the expected lifetimes and are the most consistently efficient and costeffective passive treatment systems in terms of the cost per metric ton of acid removed (PA BAMR 2009; Ziemkiewicz et al. 2003).

\section{Open Limestone Channels}

OLCs are constructed with large dimension limestone in areas with steep slopes into which AMD flows (Ziemkiewicz et al. 1994). The AMD is neutralized and oxidized by the OLC (Fig. 7), which causes precipitation of metal hydroxides. The metal hydroxides coat the limestone surfaces or plug the limestone channel, thereby retarding neutralization. Research has shown that coated (armored) limestone continues to dissolve but at a much slower rate (20\% reaction rate) than unarmored limestone (Pearson and McDonnell 1975). Ziemkiewicz et al. (1997) confirmed the slower reaction rate and found armored limestone to be $10-50 \%$ as reactive as unarmored limestone. Santomartino and Webb (2007) found limestone armoring to be comprised 
of Fe-bearing minerals including goethite and lepidocrocite, but that the limestone continued to react despite this armoring, and that armoring can be removed by agitation. Therefore, OLCs are most effective in treating AMD on steep slopes that receive periodic scouring from storm flows.

Field studies have found OLCs to be functional at many sites, and they are extremely inexpensive to construct and maintain. Seven OLCs reduced AMD acidity by 4-205 mg L $\mathrm{mg}^{-1}$, at removal rates of $0.03-19 \mathrm{mg} \mathrm{L}^{-1}$ per meter of channel length (Ziemkiewicz et al. 1997). The highest removal rates were for channels on relatively steep slopes (45-60\% slope) and highly acidic waters (500$\left.2600 \mathrm{mg} \mathrm{L}^{-1}\right)$. In another study, three OLCs were found to neutralize $30-60 \%$ of the incoming AMD acidity (Ziemkiewicz and Brant 1997). Cravotta and co-workers have experimented with OLCs for several large AMD flows with relatively low $\mathrm{Fe}\left(<10 \mathrm{mg} \mathrm{L}^{-1}\right)$ and $\mathrm{Al}$ concentrations (Cravotta 2007, 2008a, b; Cravotta and Trahan 1999; Cravotta and Ward 2008; Cravotta et al. 2004, 2008). In these systems, aerated AMD with low acidity passed through a bed of relatively coarse limestone, where $\mathrm{Fe}$ and $\mathrm{Al}$ precipitated as loose flocs and coatings. They found that much of the $\mathrm{Fe}$ and $\mathrm{Al}$ floc either washed out of the drains during storm events or had limited effect on inhibiting limestone dissolution, so effective neutralization and metal removal continued for many years. However, if the flow channelized or the water had higher Fe levels, the limestone became coated and pore spaces in the limestone channel became clogged.

OLCs are effective for a wide range of acidities and metal loadings, and they work best on slopes $>20 \%$. In practice, the slow reaction rate for armored limestone can be compensated for by extending the channel length/residence time (Ziemkiewicz et al. 1997). Flushing of coated limestone with sediment-laden water during high rainfall

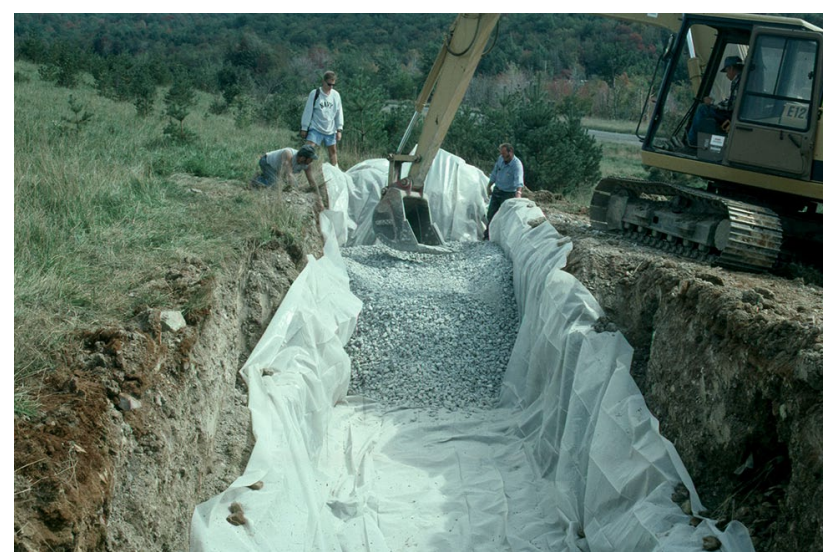

Fig. 6 Anoxic limestone drains are buried trenches of limestone. Care must be taken to introduce anoxic water with low Al concentrations (Photo: J. Skousen) events and physical agitation with heavy equipment will rejuvenate limestone treatment effectiveness by exposing fresh surfaces. In appropriate situations, OLCs are being implemented for long-term treatment. OLCs are most effective at the upstream side of a passive treatment sequence where the AMD is most acidic. OLC efficiency decreases as $\mathrm{pH}$ increases above 3.0.

\section{Limestone Leach Beds}

LLBs are small basins filled with coarse $(2-10 \mathrm{~cm}$ diameter) limestone scaled to provide at least $30 \mathrm{~min}$ of residence time (Fig. 8). They can be constructed at the upwelling of an AMD seep or in an underground mine discharge. They can be also used to pre-treat AMD with low $\mathrm{pH}(<3.0)$ and DO $\left(<1 \mathrm{mg} \mathrm{L}^{-1}\right)$ in either an upward or downward flow strategy. The latter, however, are more prone to clogging. Black et al. (1999) reported that a 30 min residence time in LLBs was sufficient to remove about $50 \%$ of the acid load from slightly acidic water ( $\mathrm{pH} 6.0, \approx 20 \mathrm{mg} \mathrm{L}^{-1}$ of influent acidity). They also found that $30 \mathrm{~min}$ of contact with limestone removed much of the proton acidity in $\mathrm{pH} 3.0$, metal-free water. Ziemkiewicz et al. (2002) reported that LLBs were useful at the upstream end of OLCs since they shortened their required length, improved their service life, and were easily serviced. LLBs can also be used as stand-alone systems. Self-flushing systems can be incorporated into LLBs to better control residence time while providing more effective floc removal.

An up-flow, manually-flushed LLB was constructed at Strattanville, PA, in 2004 to treat water with 400$650 \mathrm{mg} \mathrm{L}^{-1}$ acidity and $\mathrm{pH} 4.5$ at a flow rate of 380 $570 \mathrm{~L} \mathrm{~min}^{-1}$ (Schueck et al. 2004). The pond had an area of $61 \times 14 \mathrm{~m}$ and contained $1.3 \mathrm{~m}$ of limestone aggregate ( $2.5 \mathrm{~cm}$ maximum dimension). The water entered through perforated pipes in the bottom of the limestone layer and flowed upward to the surface. The pond was flushed downward periodically. It generated $175-250 \mathrm{mg} \mathrm{L}^{-1}$ alkalinity in the first year, but was only flushed twice during the succeeding 2 years and subsequently clogged. In 2007, the pond was expanded to about $140 \times 18 \mathrm{~m}$ area, $1.3 \mathrm{~m}$ of new limestone aggregate was placed, and a daily timed-flushing system was installed. The effluent now averages $\mathrm{pH} 5.9$ and $260 \mathrm{mg} \mathrm{L}^{-1}$ acidity. The effluent flows to a settling pond and then to a large SRB for further treatment.

LLBs have also been used to raise the alkalinity in metalfree water, which can then be mixed with AMD. Thorne and Pitzer (2003) describe two sites where LLBs were successfully used to treat acidic water containing low concentrations of dissolved metals, which then flowed to a lake resulting in restored fish populations in the lake as well as its receiving stream. Others have used LLBs to renovate outflows from other passive systems containing low concentrations 


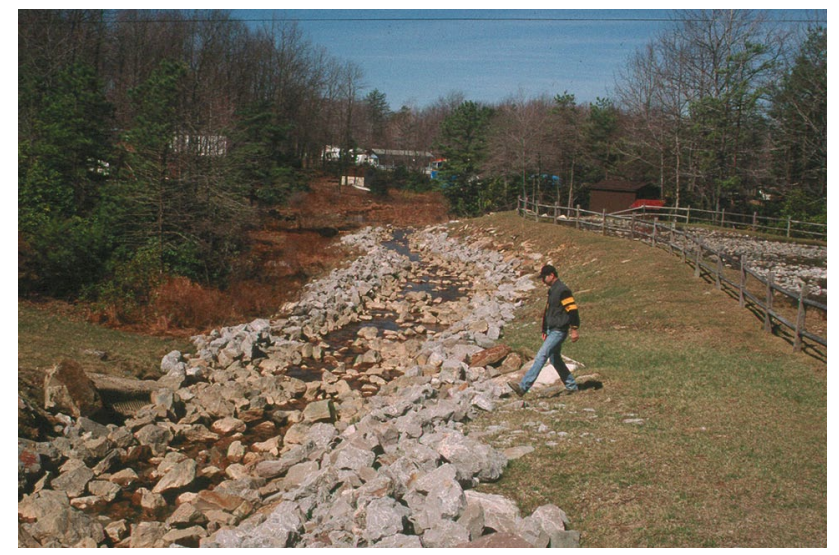

Fig. 7 Open limestone channels are streams or ditches lined with limestone rock. Although the limestone becomes coated with precipitates, dissolution and acid neutralization continues but at lower rates than for uncoated limestone rock (Photo: J. Skousen)

of remnant undesirable levels of $\mathrm{Fe}, \mathrm{Al}$, and $\mathrm{Mn}$ (Hilton et al. 2003).

A recent development has been the use of flushed LLBs to treat high-Al discharges (Hedin et al. 2013; Wolfe et al. 2010). In these systems, a bed of limestone gravel a meter or more thick is filled with AMD and then periodically flushed by opening a valve to allow rapid flow of the treated AMD out of the LLB and into a settling pond. The rapid flow flushes much of the $\mathrm{Al}$ and $\mathrm{Fe}$ hydroxide flocs from the LLB. The flushing can be performed manually or with an automated device. Experiments by Wolfe et al. (2010) show that about $50 \%$ of the floc is flushed if the LLB is drained weekly. In one experiment, a LLB received AMD with $\mathrm{pH}$ $3,10 \mathrm{mg} \mathrm{L}^{-1}$ of Fe, $15 \mathrm{mg} \mathrm{L}^{-1}$ of $\mathrm{Mn}$, and $27 \mathrm{mg} \mathrm{L}^{-1}$ of $\mathrm{Al}$ for 2 years with weekly flushing. A net-alkaline effluent was maintained during this period. After about 2 years, the limestone was cleaned by agitating it with an excavator and removing the dislodged precipitates by flushing, after which the system regained its original neutralization capability. Like OLCs, these systems require periodic maintenance to remove accumulated solids.

\section{Steel Slag Leach Beds}

Steel slag is a byproduct of steel production and is often available from metal recovery operations that mine old slag piles and grind the slag into sand to fine gravel sizes. The residual material is thus uniformly sized for use in AMD treatment. SLBs, first described by Ziemkiewicz (1998) and Ziemkiewicz and Skousen (1998), use steel slag as a cost-effective means of generating alkalinity for introduction into AMD sources. The alkalinity content (or liming potential) of steel slags ranges from 45 to $78 \% \mathrm{CaCO}_{3}$ equivalent. Ziemkiewicz and Skousen (1998) recommend the use of basic steel slags, which are distinguished from specialty (stainless) steel slags that contain higher concentrations of toxic metals such as nickel, chromium, and lead. These specialty slags should be avoided unless thoroughly characterized.

Many AMD-impaired watersheds have some uncontaminated water upstream of the AMD sources. Often this uncontaminated water is slightly acidic with little or no alkalinity, so it has little buffering effect on downstream AMD. Steel slag is used to enhance the alkalinity of these uncontaminated water sources. The slag's capacity to generate alkalinity can be estimated by jar tests since the rate of alkalinity generation when placed in water is generally very fast. With the alkalinity concentration known, the flow rate of water can be regulated to achieve a specific load of alkalinity that can be targeted to neutralize the AMD load (Ziemkiewicz 1998).

Steel slag leached with distilled water can produce an initial alkalinity of over $2000 \mathrm{mg} \mathrm{L}^{-1}$. Leachate $\mathrm{pH}$ from slag can be $>11$; the alkalinity comes from $\mathrm{CaO}$ and tri-calcium silicate minerals. The former is highly soluble and is quickly released, while the latter provides long-term, but much lessconcentrated alkalinity. Ultimately, the amount of alkalinity generated depends on particle size and contact time. SLBs should be charged with metal-free water because exposure to AMD results in rapid clogging with $\mathrm{Fe}$ and Al hydroxides (Ziemkiewicz 1998). Even with metal-free water, the high $\mathrm{pH}$ of these beds will result in carbonization and calcite formation which will cause clogging over time; this can be minimized by maintaining a water cap over the slag.

Simmons et al. (2002a, b) used check dams made of fine steel slag and limestone, in combination with an OLC, to treat several small flows of water with acidities of 12-30 $\mathrm{mg} \mathrm{L}^{-1}$, and a $\mathrm{pH}$ of 4.1-5.0. The LLB-SLB system generated effluents with an alkalinity of $170-225 \mathrm{mg} \mathrm{L}^{-1}$ and a $\mathrm{pH}$ of 8-9.5 for over a year. In Ohio, extensive

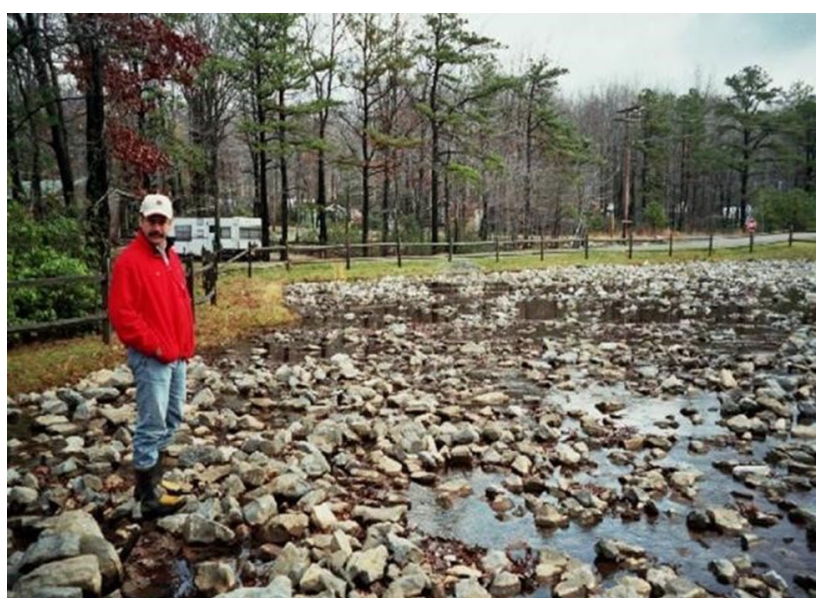

Fig. 8 Limestone leach beds add alkalinity to fresh water, which can then be mixed with AMD for treatment (Photo: J. Skousen) 
reclamation efforts at the Broken Aro Mine have used SLBs receiving both AMD and metal-free water (Laverty et al. 2007). The SLBs have been used in combination with surface water diversion, VFWs, settling ponds, and other technologies to remediate this highly polluted area. The SLBs, which contained about 10,000 t of steel slag, contributed large amounts of alkalinity, causing the acid load from the area to decrease by $700 \mathrm{~kg} \mathrm{day}^{-1}$. Successful water treatment was similarly attained using SLBs and other techniques at the Huff Run watershed in Ohio (Hamilton et al. 2007).

\section{Diversion Wells}

A diversion well is a simple device, initially developed for treatment of rainfall-induced stream acidity in Norway and Sweden (Arnold 1991), and has been adopted for AMD treatment in the eastern USA. A typical diversion well consists of a cylinder or vertical tank of metal or concrete, $1.5-1.8 \mathrm{~m}$ in diameter and $2-2.5 \mathrm{~m}$ in depth, and filled with sand-sized limestone erected in or beside a stream or sunk into the ground beside a stream (Fig. 9). A large pipe, $20-30 \mathrm{~cm}$ in diameter, enters vertically down the center of the well and ends shortly above the bottom. Acidic water is fed to the pipe from an upstream dam or deep mine portal with a hydraulic head of at least $2.5 \mathrm{~m}$ (above the well height). The incoming water exits the pipe near the bottom of the diversion well under pressure and then flows back up through the limestone in the well, thereby fluidizing the bed of limestone in the well. The flow rate and water energy must be large enough to agitate and fluidize the bed of limestone particles. The acidic water dissolves the limestone, generating alkalinity; metal flocs produced by hydrolysis and neutralization reactions are kept suspended and are flushed through the system by the water current out through the top of the well. The churning action of the fluidized limestone also aids limestone dissolution and helps remove Fe hydroxide coatings so that fresh limestone surfaces are continually exposed. Metal flocs suspended in the water can be settled in a downstream settling pond. The limestone in the well must be replenished frequently, commonly weekly to monthly, depending on water flow and acidity concentrations.

Arnold (1991) used diversion wells for AMD treatment in PA and reported that three wells increased $\mathrm{pH}$ in the stream from 4.5 to 6.5 , with corresponding decreases in acidity. Diversion wells reduced water acidity by $60 \%$ at the Casselman River (Ziemkiewicz and Brant 1997). At the Galt site in WV, a diversion well increased $\mathrm{pH}$ from 3.1 to 5.5 and reduced acidity from 278 to $86 \mathrm{mg} \mathrm{L}^{-1}$, a $70 \%$ reduction (Faulkner and Skousen 1995). Pulsing systems have also been devised to increase the alkalinity from diversion wells (Sibrell et al. 2005, 2013).

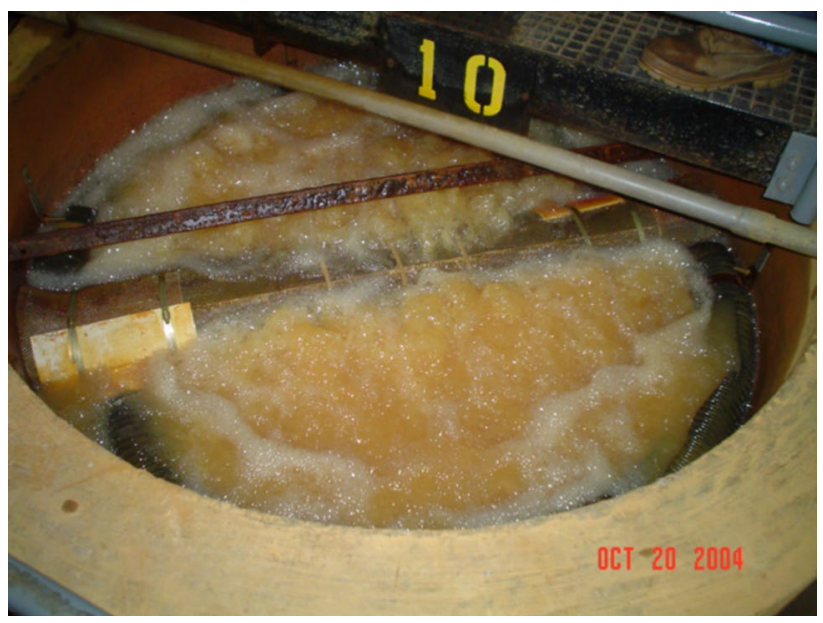

Fig. 9 Diversion wells are cylindrical concrete or metal tanks filled with limestone. A metal pipe extends down the length of the tank and carries AMD to the bottom of the tank under pressure to agitate and fluidize the limestone in the tank to minimize coating and enhance dissolution (Photo: J. Skousen)

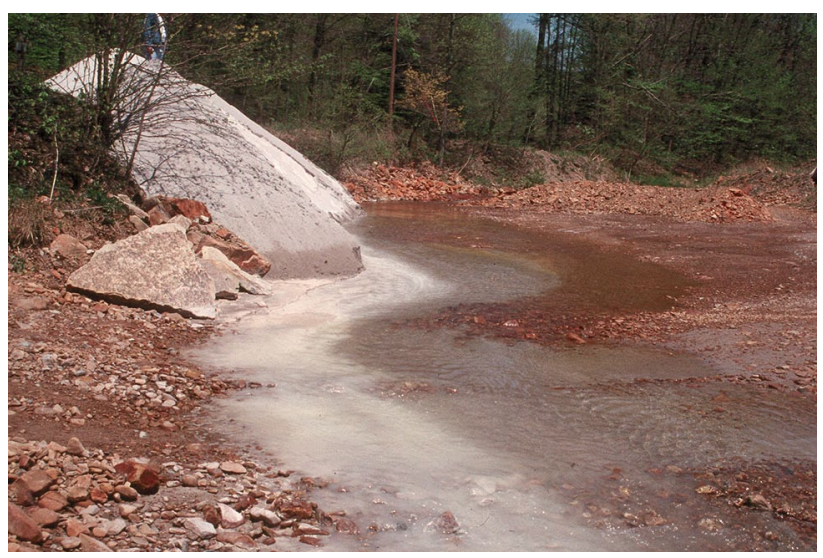

Fig. 10 Limestone sand can be placed in polluted streams to treat AMD. The turbulence in the stream aids limestone dissolution and minimizes metal-precipitate armoring, improving its effectiveness (Photo: J. Skousen)

\section{Limestone Sand Treatment}

LS sand treatment is the addition of sand-sized limestone to streams in a watershed (Zurbuch 1996). The sand is suspended by the streamflow and redistributed downstream, neutralizing acid as the energy of the stream transports the limestone (Fig. 10). Coating of limestone particles with Fe hydroxides can occur, but the energy of the water in the stream causes agitation and scouring of limestone to keep fresh limestone surfaces available for reaction. This technology can be more cost effective on a watershed scale than more conventional passive treatment of AMD discharges if resources for continued additions of limestone sand are available. 
The State of West Virginia used limestone sand additions to restore several river systems. About $450 \mathrm{~km}$ of streams affected by acid deposition and AMD were treated. For example, in the Middle Fork River, 41 sites in tributary headwaters were loaded with limestone sand (Zurbuch 1996). Based on the annual acid load of the river $\left(2000 \mathrm{t} \mathrm{year}^{-1}\right), 500 \mathrm{t}$ of limestone sand were added at 3 month intervals (quarterly). The $\mathrm{pH}$ has been maintained above 6.0 for several km downstream of the treatment sites and the anticipated coating on the limestone sand was not observed. Quarterly additions of limestone sand will be required to maintain water quality for fish populations over an extended period. A follow-up study (Brown 2005) reported continued success of the West Virginia limestone sand treatment project. River $\mathrm{pH}$ of the Middle Fork increased from 4.9 to 6.8 , with conversion from net-acidic to net-alkaline water. A section of $200 \mathrm{~km}$ was restored to a trout fishery by this method. McClurg et al. (2007) studied the effects of limestone sand immediately downstream of application points. Small increases in $\mathrm{Fe}$ and $\mathrm{Ca}$ were observed in sediments within $100 \mathrm{~m}$ of the treatment site.

Constant addition of limestone sand or hydrated lime from a silo through an automatic feeder (doser) has shown good results in Maryland (Mills J., Personal communications on stream dosing and slag beds, MD Bureau of Mines, 2009). Dosers on severely contaminated streams have led to fish recovery in the Potomac River and several tributaries. The stream immediately below the limestone sand doser is impacted by $\mathrm{Fe}$ and Ca flocs, but most of the stream is greatly improved. Dosers have been installed on several streams and discharges in Pennsylvania. Thus, limestone sand application has been demonstrated to be an effective technique to restore fisheries in large watersheds.

\section{Low-pH Fe Oxidation Channels}

Low-pH Fe oxidation channels are a relatively recent innovation that can be used to partially treat high $\mathrm{Fe}$ discharges (Burgos et al. 2008; Hilton 2005). A shallow channel is constructed and lined with limestone or sandstone aggregate to enhance $\mathrm{Fe}$ oxidation and to promote adsorption and coprecipitation on rocks in conjunction with $\mathrm{Fe}$-oxidizing bacteria. At a pH above 4.5, the rate of $\mathrm{Fe}^{2+}$ oxidation increases markedly by combinations of abiotic and biotic catalysis, but at a pH below about 3.5, the process can be catalyzed by specialized bacteria. A number of sites where this occurs naturally have been identified (Hilton 2005). At these sites, channel slopes and wide flow paths enable adequate air contact (Fig. 11). $\mathrm{Fe}^{2+}$ is oxidized to $\mathrm{Fe}^{3+}$, some of which precipitates, thereby decreasing dissolved metal concentrations. In the absence of limestone, the $\mathrm{pH}$ decreases from the released $\mathrm{H}^{+}$and the acidity remains very low, but subsequent treatment of the acid is easier. At some sites, nearly all of the dissolved Fe was removed (Hilton 2005). The low-pH

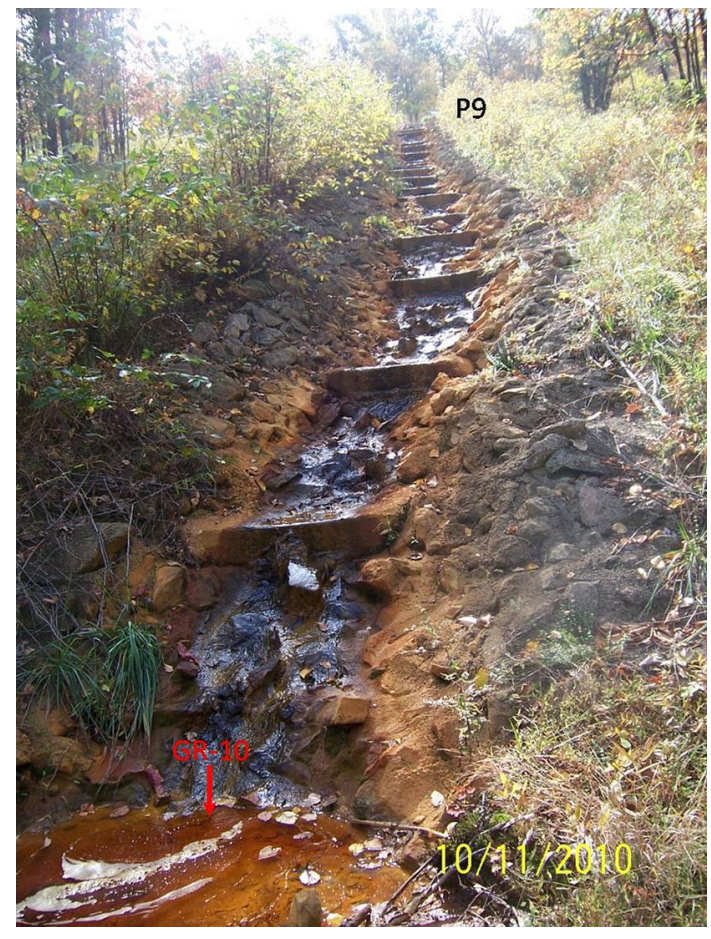

Fig. 11 Low pH Fe oxidation channels can remove Fe concentrations in water even when water $\mathrm{pH}$ is low (Photo: T. Danehy)

oxidation channels removed some Fe, but removal efficiencies have not yet been determined.

\section{Summary}

The eastern USA has a long history of dealing with AMD from mining operations. Over the past several decades, a number of researchers and reclamation practitioners have contributed to the development of AMD passive treatment designs and science. With careful design and construction, systems can be effective over a wide range of metal and acidity concentrations. Relative to chemical treatment, passive systems require longer retention times and larger land areas. They are subject to failure if poorly designed and constructed, particularly if not correctly scaled to the target discharge flow and acid and specific metal concentrations. At their present stage of development, passive systems work well on low volume AMD discharges $\left(<400 \mathrm{~L} \mathrm{~min}^{-1}\right)$ containing moderate to high acidity and metals. Passive systems have been shown to effectively treat larger flows (up to $10,000 \mathrm{~L} \mathrm{~min}^{-1}$ ) for net alkaline water containing Fe.

A critical activity in passive treatment is the selection of the proper system type for a given situation. Factors to be considered in selection include the quality and quantity of waters to be treated, water treatment goals, access, and the land resources available for use in system construction (Fig. 1). Generally, larger land areas (relative to anticipated 
acid loads) enable more effective treatment, and essential design features for all systems include surface area and/or volume (Table 1). However, specialized systems that require significant initial cost and regular maintenance (e.g. VFWs, bioreactors) are available for use where land areas are insufficient for traditional passive systems such as AnWs. Design factors, including those that are unique to certain system types, are described above.

Passive systems have substantially reduced water treatment costs at many mine sites (Skousen and Ziemkiewicz 2005). Capital, maintenance, and operating costs are generally much lower than for active systems. Passive systems can reliably produce high quality discharges if properly designed, constructed, and maintained (Hedin et al. 2013). However, active treatment is often favored in settings where discharge quality is a regulatory requirement. Passive treatment is more suited for watershed-based AMD control schemes where high standards or specific effluent limits are not required at each discharge. In some cases, passive treatment is appropriate for regulated discharges at unstaffed and remote locations, where active-treatment operating risks and costs are especially high and where location characteristics allow for passive-system overdesign.

Essentially all passive treatment systems require some degree of maintenance. The precipitates formed in passive systems are denser than those generated in active systems, so sludge handling is generally easier and less frequent. If settling ponds are adequately sized, cleanout may not be needed. Although periodic monitoring and maintenance is essential, the need is much less than in active systems. At a minimum, the systems should be inspected every few months for impediments to flow, leakage, and inadequate treatment. In addition, more extensive maintenance, such as replenishment of the alkaline reagent or organic matter substrate, and removal of accumulated metal precipitates, is occasionally required. Experience suggests that rehabilitation is typically required every $5-10$ years, though that time will be influenced by system size and design.

\section{Conclusions}

The science and practice of passive treatment for AMD have progressed over several decades. Numerous options are available to water managers who wish to use passive treatment to mitigate AMD discharges, but knowledge of site characteristics remains essential to successful passive system selection and design. Continued evaluation of passive system performance is needed across a variety of system types and across a wide range of water flows and chemistries, as such information will improve our understanding of how system design can enhance water treatment effectiveness. Improved strategies for maintaining these systems' acid-removal efficiencies over longer terms are needed, as are design features that can ease essential maintenance tasks and increase functional lifetimes.

AMD remains a problem in mining districts throughout the world, so the passive treatment technologies described in this paper have the potential for broad application. Continued development of new technologies and improvement of known systems through observation and research will undoubtedly further increase efficiencies and extend effectiveness for a broader range of water types and flows and different climatic environments.

Open Access This article is distributed under the terms of the Creative Commons Attribution 4.0 International License (http://creativecommons.org/licenses/by/4.0/), which permits unrestricted use, distribution, and reproduction in any medium, provided you give appropriate credit to the original author(s) and the source, provide a link to the Creative Commons license, and indicate if changes were made.

\section{References}

APHA (American Public Health Association) (1998) Acidity (2310)/ titration method. In: Clesceri LS, Greenberg AE, Eaton AD (eds) Standard methods for the examination of water and wastewater, 20th edn. American Public Health Association, Washington, pp 2.24-2.26

Arnold DE (1991) Diversion wells - a low-cost approach to treatment of acid mine drainage. In: Proceedings of the 12th West Virginia surface mine drainage task force symposium, Morgantown, WV

Bechard G, Yamazaki H, Gould WD, Bedard P (1994) Use of cellulosic substrates for the microbial treatment of acid mine drainage. J Environ Qual 23:111-116

Black C, Ziemkiewicz P, Skousen J (1999) Construction of a limestone leach bed and preliminary water quality results in Beaver Creek. In: Proceedings of the 20th West Virginia surface mine drainage task force symposium, Morgantown, WV

Brock TD, Madigan MT, Martinko JM, Parker J (1994) Biology of microorganisms, 7th edn. Prentice Hall, Englewood Cliffs

Brodie GA (1993) Staged, aerobic constructed wetlands to treat acid drainage: case history of Fabius Impoundment 1 and overview of the Tennessee Valley Authority's Program. In: Moshiri GA (ed) Constructed wetlands for water quality improvement. Lewis, Boca Raton, pp 157-166

Brodie GA, Britt CR, Tomaszewski TM, Taylor HN (1991) Use of passive anoxic limestone drains to enhance performance of acid drainage treatment wetlands. In: Proceedings of the 7th ASMR, Durango, CO, pp 211-222

Brooks R, Samuel DE, Hill JB (eds) (1985) Wetlands and water management on mined lands conf. In: Proceedings. The Pennsylvania State University, University Park, PA

Brown WS (2005) Instream limestone sand treatment of the Middle Fork watershed. In: Proceedings of the 26th West Virginia surface mine drainage task force symposium, Morgantown, WV

Buccambuso E, Ruhs A, Figueroa L, Gusek JJ, Wildman T, Holmes M, Reisman D (2007) Ethanol-fed or solid-phase organic sulfate reducing bioreactors for the National Tunnel Drainage, Clear Creek/Central City Superfund site? In: Proceedings of the 24th ASMR, Gillette, WY, pp 95-105 
Burgos WD, Senko JM, Bruns MA (2008) Low pH Fe(II) oxidation incorporated into passive treatment. In: Proceedings of the 29th West Virginia surface mine drainage task force symposium, Morgantown, WV

Casiot C, Egal M, Elbaz-Poulichet F, Bruneel O, Bancon-Montigny C, Cordier M, Gomez E, Aliaume C (2009) Hydrological and geochemical control of metals and arsenic in a Mediterranean river contaminated by acid mine drainage: preliminary assessment of impact on fish (Leuciscus cephalus). Appl Geochem 24:787-799

Chang IS, Shin PK, Kim BH (2000) Biological treatment of acid mine drainage under sulfate reducing conditions with solid waste materials as substrate. Water Res 34:1269-1277

Cheong YW, Min JS, Kwon KS (1998) Metal removal efficiencies of substrates for treating acid mine drainage of the Dalsung mine, South Korea. J Geochem Explor 64:147-152

Cherry D, Currie R, Soucek D, Latimer D, Grent G (2001) An integrative assessment of a watershed impacted by abandoned mined land discharges. Environ Pollut 111:377-388

Ciccarelli JM, Weber PA, Stewart WS, Li J, Schumann R, Miller SD, Smart R StC (2009). Estimation of long-term silicate neutralization of acid rock drainage. In: Proceedings of the 8th International Conf on Acid Rock Drainage (8 ICARD), Skellefteå, Sweden, pp 1-12

Cocos IA, Zagury GJ, Clement B, Samson R (2002) Multiple factor design for reactive mixture selection for use in reactive walls in mine drainage treatment. Water Res 36:167-177

Cravotta CA (2003) Size and performance of anoxic limestone drains to neutralize acidic mine drainage. J Environ Qual 32:1277-1289

Cravotta CA (2007) Passive aerobic treatment of net-alkaline, ironladen drainage from a flooded underground anthracite mine, Pennsylvania, USA. Mine Water Environ 26:128-149

Cravotta CA (2008a) Dissolved metals and associated constituents in abandoned coal-mine discharges, Pennsylvania, USA. Part 1: constituent quantities and correlations. Appl Geochem 23:166-202

Cravotta CA (2008b) Laboratory and field evaluation of a flushable oxic limestone drain for treatment of net-acidic, metal-laden drainage from a flooded anthracite mine, Pennsylvania, USA. Appl Geochem 23:3404-3422

Cravotta CA, Kirby C (2004) Acidity and alkalinity in mine drainage: Practical considerations. In: Proceedings of the 21st ASMR and the 25th West Virginia surface mine drainage task force symposium, Morgantown, WV, pp 334-365

Cravotta CA, Trahan M (1999) Limestone drains to increase $\mathrm{pH}$ and remove dissolved metals from acidic mine drainage. Appl Geochem 14:581-606

Cravotta CA, Ward SJ (2008) Downflow limestone beds for treatment of net-acidic, oxic, iron-laden drainage from a flooded anthracite mine, Pennsylvania, USA 1. Field evaluation. Mine Water Environ $27: 67-85$

Cravotta CA, Watzlaf GR (2002) Design and performance of limestone drains to increase $\mathrm{pH}$ and remove dissolved metals from acidic mine drainage. In: Naftz DL, Morrison SJ, Davis JA, Fuller $\mathrm{CC}$ (eds) Handbook of groundwater remediation using permeable reactive barriers. Academic Press, Amsterdam, pp 19-66

Cravotta CA, Ward SJ, Khoury DJ, Koch RD (2004) Optimization of limestone drains for long-term treatment of mine drainage, Swatara Creek basin, Schuylkill County, PA. In: Proceedings of the 21st ASMR and the 25th West Virginia surface mine drainage task force symposium, Morgantown, WV

Cravotta CA, Ward SJ, Hammerstrom JM (2008) Downflow limestone beds for treatment of net-acidic, oxic, iron-laden drainage from a flooded anthracite mine, Pennsylvania, USA-2. Laboratory evaluation. Mine Water Environ 27:86-99

Danehy TP, Hilton T, Watzlaf GR, Johnson F, Busler SL, Denholm CF, Dunn MH (2002) Vertical flow pond piping system design considerations. In: Proceedings of the 19th ASMR, Duluth, MN, pp 916-934
Daubert LN, Brennan RA (2007) Passive remediation of acid mine drainage using crab shell chitin. Environ Eng Sci 24:1353-1358

David C (2003) Establishing the impact of acid mine drainage through metal bioaccumulation and taxa richness of benthic insects in a tropical Asian stream. Environ Tox Chem 22:2952-2959

Davies SH, Morgan JJ (1989) Manganese (II) oxidation kinetics on metal oxide surfaces. J Colloid Interf Sci 129:63-77

Drury WJ (1999) Treatment of acid mine drainage with anaerobic solid-substrate reactors. Water Environ Res 71:1244-1250

Duddleston KN, Fritz E, Hendricks A, Roddenberry K (1992) Anoxic cattail wetland for treatment of water associated with coal mining activities. In: Proceedings of the 9th ASMR, Duluth, MN, pp 249-254

Dvorak DH, Hedin RS, Edenborn HM, McIntire PE (1992) Treatment of metal contaminated water using bacterial sulfate reduction: results from pilot scale reactors. Biotech Bioeng 40:609-616

Emerson S, KalhornS, Jacobs L, Tebo BM, Nealson KH, Rosson RA (1982) Environmental oxidation rate of Mn(II): bacterial catalysis. Geochim Cosmochim Acta 46:1073-1079

Evangelou VP (1995) Pyrite oxidation and its control. CRC Press, Boca Raton

Faulkner BB, Skousen J (1994) Treatment of acid mine drainage by passive treatment systems. International land reclamation and mine drainage conference, US Bureau of Mines SP 06A-94, Pittsburgh, PA, pp 250-257

Faulkner BB, Skousen J (1995) Effects of land reclamation and passive treatment systems on improving water quality. Green Lands 25:34-40

Figueroa L, Miller A, Zaluski M, Bless DR (2007) Evaluation of a twostage passive treatment approach for mining influenced waters. In: Proceedings of the 24th ASMR, Gillette, WY, pp 238-247

Ghiorse WC (1984) Biology of the iron- and manganese-depositing bacteria. Annu Rev Microbiol 38:515-550

Ghiorse WC, Ehrlich HL (1992) Microbial biomineralization of iron and manganese. Biomineralization processes of iron and manganese. In: Skinner HCW, Fitzpatrick RW (eds) Catena, supplement 21, pp 75-100

Gibert O, de Pablo J, Cortina JL, Ayora C (2004) Chemical characterization of natural organic substrates for biological mitigation of acid mine drainage. Water Res 38:4186-4196

Glombitza F (2001) Treatment of acid lignite mine flooding water by means of microbial sulfate reduction. Waste Manage 21:197-203

Gray N, Delaney E (2008) Comparison of benthic macroinvertebrate indices for the assessment of the impact of acid mine drainage on an Irish river below an abandoned $\mathrm{Cu}-\mathrm{S}$ mine. Environ Poll 155:31-40

Gregory E, Staley JT (1982) Widespread distribution of ability to oxidize manganese among freshwater bacteria. Appl Environ Microbiol 46:1073-1079

Gusek JJ (2004) Scaling up design challenges for large scale sulfate reducing bioreactors. In: Proceedings of the 21 st ASMR and the 25th West Virginia surface mine drainage task force symposium, Morgantown, WV, pp 752-765

Gusek JJ, Schueck J (2004) Bench and pilot scale test results: passive treatment of acid mine drainage at the Fran Coal Mine, PA. Tailings and mine waste. In: Proceedings of the 11th tailings and mine waste conference, pp 267-272

Hamilton J, Gue J, Socotch C (2007) The use of steel slag in passive treatment design for AMD discharge in the Huff Run watershed restoration. In: Proceedings of the 24th ASMR, Gillette, WY, pp 272-282

Harris MA, Ragusa S (2001) Bioremediation of acid mine drainage using decomposable plant material in a constant flow bioreactor. Environ Geol 40:1192-1204

Hedin RS, Nairn R (1992) Designing and sizing passive mine drainage treatment systems. In: Proceedings of the 30th West Virginia surface mine drainage task force symposium, Morgantown, WV 
Hedin RS, Nairn R, Kleinmann RLP (1994) Passive treatment of coal mine drainage. US Bureau of Mines IC 9389, Pittsburgh, PA

Hedin RS, Watzlaf GR, Nairn RW (1994) Passive treatment of acid mine drainage with limestone. J Environ Qual 23:1338-1345

Hedin RS, Weaver T, Wolfe N, Weaver K (2010) Passive treatment of acidic coal mine drainage: the Anna $\mathrm{S}$ Mine passive treatment complex. Mine Water Environ 29:165-175

Hedin RS, Weaver T, Wolfe N, Watzlaf G (2013) Effective passive treatment of coal mine drainage. In: Proceedings of the 35th National association of abandoned mine land programs conference, Daniels, WV, USA

Hendricks AC (1991) The use of an artificial wetland to treat acid mine drainage. In: Proceedings of the 2nd ICARD, Montreal, Canada

Herlihy AT, Kaufmann PR, Mitch ME, Brown DD (1990) Regional estimates of acid mine drainage impact on streams in the midAtlantic and southeastern United States. Water Air Soil Poll 50:91-107

Hilton T (2005) Low pH-iron oxidation. In: Proceedings of the 26th West Virginia surface mine drainage task force symposium, Morgantown, WV

Hilton T, Dunn M, Danehy T, Busler S (2003) Harbison-Walker-a hybrid passive treatment system. In: Proceedings of the 24th West Virginia surface mine drainage task force symposium, Morgantown, WV

Huminicki DMC, Rimstidt JD (2007) Anoxic limestone drain (ALD) design: role of calcite dissolution kinetics and gypsum coatings. Appl Geochem 23:148-165

Huntsman BE, Solch JG, Porter MO (1978) Utilization of Sphagnum species dominated bog for coal acid mine drainage abatement. Abstracts, 91st annual meeting. Geological Society of America, Toronto, ON, Canada, p 322

Jage CR, Zipper CE, Hendricks AC (2000) Factors affecting performance of successive alkalinity producing systems. In: Proceedings of the 17th ASMR, Tampa, FL, pp 451-458

Jage CR, Zipper CE, Noble R (2001) Factors affecting alkalinity generation by successive alkalinity producing systems: regression analysis. J Environ Qual 30:1015-1022

Janin A, Harrington J (2015) Performances of lab-scale anaerobic bioreactors at low temperature using Yukon native microorganisms. In: Proceedings of the mine water solutions in extreme environments, Vancouver, Canada, pp 519-532

Jenne EA (1968) Controls on $\mathrm{Mn}, \mathrm{Fe}, \mathrm{Co}, \mathrm{Ni}, \mathrm{Cu}$ and $\mathrm{Zn}$ concentrations in soils and water: the significant role of hydrous $\mathrm{Mn}$ and $\mathrm{Fe}$ oxides. Trace inorganics in water. American Chemical Society, pp 337-387

Ji S, Kim S, Ko J (2008) The status of the passive treatment systems for acid mine drainage in South Korea. Environ Geol 55:1181-1194

Johnson DB, Hallberg KB (2005) Acid mine drainage remediation options: a review. Sci Total Environ 338:3-14

Kepler DA, McCleary EC (1994) Successive alkalinity-producing systems (SAPS) for the treatment of acidic mine drainage. US bureau of mines special paper SP 06A-94, Pittsburgh, PA, pp 195-204

Kepler DA, McCleary EC (1997) Passive aluminum treatment success. In: Proceedings of the 18th West Virginia surface mine drainage task force symposium, Morgantown, WV

Kepler DA, McCleary EC (2003) Successive alkalinity producing systems by Damariscotta. In: Proceedings of the 24th West Virginia Surface mine drainage task force symposium, Morgantown, WV

Kirby CS, Cravotta CA (2005a) Net alkalinity and net acidity 1: theoretical considerations. Appl Geochem 20:1920-1940

Kirby CS, Cravotta CA (2005b) Net alkalinity and net acidity 2: practical considerations. Appl Geochem 20:1941-1964

Kleinmann, RLP (1985) Treatment of acid mine water by wetlands. Control of acid mine drainage. BuMines IC 9027, pp 48-52

Kleinmann RLP (1989). Acid mine drainage. Eng Mining J $190: 16 \mathrm{I}-16 \mathrm{~N}$
Kleinmann RLP (1991) Biological treatment of mine water-an overview. In: Proceedings of the 2nd ICARD, Montreal, Canada, pp 27-42

Kleinmann, RLP, Tiernan TO, Solch JG, Harris RL (1983) A low cost, low maintenance treatment system for acid mine drainage using sphagnum moss and limestone. In: Graves DH (ed) Proceedings of the 1983 symposium on surface mining, hydrology, sedimentology and reclamation, University of Kentucky, Lexington, KY, pp 241-246

Kuyucak N, Chabot F, Martschuk J (2006) Successful implementation and operation of a passive treatment system in an extremely cold climate, northern Quebec, Canada. In: Proceedings of the 7th ICARD, St. Louis MO, pp 980-992

LaBar JA, Nairn RW, Canty GA (2008) Generation of 400-500 mg/L alkalinity in a vertical anoxic limestone drain. In: Proceedings of the 25th ASMR, Richmond, VA, pp 551-563

Laverty B, McCament B, Farley ME (2007) Performance of steel slag and other passive treatment systems at the Broken Aro mine in Little Raccoon Creek, Ohio. In: Proceedings of the 28th West Virginia surface mine drainage task force symposium, Morgantown, WV

Lewis DM (1976) The geochemistry of manganese, iron, uranium, lead 210, and major ions in the Susquehanna River. PhD thesis, Yale University, New Haven, CN, USA

Lindow NL, Borden RC (2004) Anaerobic bioremediation of acid mine drainage using EOS. In: Proceedings of the 21st ASMR and the 25th West Virginia surface mine drainage task force symposium, Morgantown, WV

Lindow NL, Borden RC (2005) Anaerobic bioremediation of acid mine drainage using emulsified soybean oil. Mine Water Environ 24:199-208

Lindsay MBJ, Blowes DW, Condon PD, Ptacek CJ (2011) Organic carbon amendments for passive in situ treatment of mine drainage. Appl Geochem 26:1169-1183

Luan F, Santelli CM, Hausel CM, Burgos WB (2012) Defining manganese (II) removal processes in passive coal mine drainage treatment systems through laboratory incubation experiments. Appl Geochem 27:1567-1578

Marshall KC (1979) Biogeochemistry of manganese minerals, ch 5, biogeochemical cycling of mineral-forming elements. Elsevier, New York, pp 253-292

McCauley CA, O'Sullivan AD, Weber PA, Trumm DA (2008) Performance of mesocosm sulfate-reducing bioreactors for treating acid mine drainage in New Zealand. In: Proceedings of the 25th ASMR, Richmond, VA, pp 662-698

McClurg SE, Petty JT, Mazik PM, Clayton JL (2007) Stream ecosystem response to limestone treatment in acid impacted watersheds of the Allegheny Plateau. Ecol Appl 17:1087-1104

McCullough CD, Lund MA, May JM (2006) Microcosm testing of municipal sewage and green waste for full-scale remediation of an acid coal pit lake, in semi-arid tropical Australia. In: Proceedings of the 7th ICARD, St. Louis MO, pp 1177-1197

McGregor R, Blowes D, Ludwig R, Choi M (2000) The use of an insitu porous reactive wall to remediate a heavy metal plume. In: Proceedings of the 5th ICARD, Denver, CO, pp 1227-1232

Means B, Rose AW (2005) Rate of manganese removal in limestone bed systems. In: Proceedings of the 22nd ASMR, Breckenridge, CO, pp 702-716

Miller S, Stewart W, Rusdinar Y, Schumann R, Ciccarelli J, Li J, Smart RStC (2010) Methods for estimation of long-term noncarbonate neutralization of acid rock drainage. Sci Total Environ 408:2129-2135

Mukhopadhyay B, Bastias L, Mukhopadhyay A (2007) Limestone drain design parameters for acid rock drainage mitigation. Mine Water Environ 26:29-45 
Mustoe GE (1979) Bacterial oxidation of manganese and iron in a modern cold spring. Geoll Soc Am Bull 92(1):147-153

Nairn RW, Hedin R, Watzlaf G (1991) A preliminary review of the use of anoxic limestone drains in the passive treatment of acid mine drainage. In: Proceedings of the 12th West Virginia surface mine drainage task force symposium, Morgantown, WV

Nairn RW, Hedin RS, Watzlaf GR (1992) Generation of alkalinity in an anoxic limestone drain. In: Proceedings of the 9th ASMR, Duluth, MN, pp 206-219

Neculita CM, Zagury GJ (2008) Biological treatment of highly contaminated acid mine drainage in batch reactors: long-term treatment and reactive mixture characterization. J Haz Mat 157:358-366

Neculita CM, Zagury GJ, Bussiere B (2007) Passive treatment of acid mine drainage in bioreactors using sulfate-reducing bacteria: critical review and research needs. J Environ Qual 36:1-16

Newcombe CE, Brennan RA (2008) Chitin as a fractional amendment to spent mushroom compost to enhance the efficiency and effectiveness of treatment of mine-impacted water. In: Proceedings of the 25th ASMR, Richmond, VA, pp 14-19

Newcombe CE, Brennan RA (2010) Improved passive treatment of acid mine drainage in mushroom compost amended with crabshell chitin. J Environ Eng 136:616-626

Nordstrom DK (2011) Mine waters: acidic to circumneutral. Elements 7:393-398

Nordwick S, Zaluski M, Park B, Bless DR (2006) Advances in development of bioreactors applicable to the treatment of ARD. In: Proceedings of the 7th ICARD, St. Louis MO, pp 1410-1420

PA BAMR (PA Bureau of Abandoned Mine Reclamation) (2009) Acid mine drainage set-aside program: program implementation guidelines. PA Department of Environmental Protection, Harrisburg, PA, pp 66

Pearson FH, McDonnell AJ (1975) Use of crushed limestone to neutralize acid wastes. No. EE1, Proceeding Paper 11131. J Environ Eng Div Soc Civil Eng 101:139-158

Place DL, Figueroa L, Wildeman T, Reisman D (2006) Characterizing and tracking reactive mixture alteration: new tools for passive treatment design and monitoring. In: Proceedings of the 7th ICARD, St. Louis, MO, pp 25-30

Prieto MV, Hiibel SR, Pereyra LP, Pruden A, Reardon KF, Reisman D (2008) Effect of organic substrate composition on microbial community structure of pilot-scale biochemical reactors treating mining influenced water. In: Proceedings of the 25th ASMR, Richmond, VA, pp. 878-891

Robbins EI, Brant DL, Ziemkiewicz PF (1999) Microbial, algal and fungal strategies for manganese oxidation at a Shade Township coal mine, Somerset County, PA. In: Proceedings of the 16th ASMR, Scottsdale, AZ, pp 634-640

Robinson-Lora MA, Brennan RA (2010) Chitin complex for the remediation of mine-impacted water: geochemistry of metal removal and comparison with other common substrates. Appl Geochem 25:336-344

Rose AW (2003) Performance of vertical flow systems for passive treatment of acid mine drainage. In: Proceedings of the 6th ICARD, Cairns, Australia, pp 809-815

Rose AW (2004a) Vertical flow systems - Effects of time and acidity relations. In: Proceedings of the 21st ASMR and the 25th West Virginia surface mine drainage task force symposium, Morgantown, WV, pp 1595-1616

Rose AW (2004b) Studies of poorly performing vertical flow ponds treating acid mine drainage. In: Proceedings of the 4th Ohio division of mineral resource management applied research conference, Athens, $\mathrm{OH}$

Rose AW (2006) Long-term performance of vertical flow pondsan update. In: Proceedings of the 7th ICARD, St. Louis, MO, pp 1704-1716
Rose AW (2010) Advances in passive treatment of coal mine drainage 1998-2009. In: Proceedings of the 27th ASMR, Pittsburgh, PA, pp 847-887

Rose AW (2013) An evaluation of passive treatment systems receiving oxic net acidic mine drainage. Report to PA Bureau of Abandoned Mine Reclamation, Harrisburg, PA, p 27

Rose AW, Dietz J (2002) Case studies of passive treatment systems: vertical flow systems. In: Proceedings of the 19th ASMR, Lexington, KY, pp 776-797

Rose AW, Alcorn G, Phelps L, Bower P (2001) Case study of pot ridge passive treatment systems, Cambria County, Pennsylvania. In: Proceedings of the 18th ASMR, Albuquerque, NM, pp 592-603

Rose AW, Shah PJ, Means B (2003a) Case studies of limestone bed passive systems for manganese removal from acid mine drainage. In: Proceedings of the 20th ASMR, Billings, MT, pp 1059-1078

Rose AW, Means B, Shah P (2003b) Methods for passive removal of manganese from acid mine drainage. In: Proceedings of the 24th WV Surface Mine drainage task force symposium, Morgantown, WV

Rose AW, Bisko D, Daniel A, Bower MA, Heckman S (2004) An "autopsy" of the failed Tangascootack \#1 vertical flow pond, Clinton Co., Pennsylvania. In: Proceedings of the 21st ASMR and the 25th WV surface mine drainage task force symposium, Morgantown, WV, pp 1580-1594

Rose AW, Morrow T, Dunn M, Denholm C (2007) Mode of gypsum precipitation in vertical flow ponds. In: Proceedings of the 24th ASMR, Gillette, WY, pp 678-691

Rutkowski T, Hanson R, Conroy K (2013) Mine water treatment options for meeting stringent selenium regulatory limits. In: Brown A, Figeroa L, Wolkersdorfer C (Eds) Proceedings of the international mine water association, pp 711-716

Samuel DE, Sencindiver J, Rauch H (1988) Water and soil parameters affecting growth of cattails. In: Mine drainage and surface mine reclamation, vol 1, IC 9183. US Bureau of Mines, Pittsburgh, pp 367-374

Sandy T, DiSante C (2010). Review of available technologies for the removal of selenium from water. $\mathrm{CH} 2 \mathrm{M}$ Hill, Charlotte, $\mathrm{NC}$, http://namc.org/docs/00062756.PDF

Santomartino S, Webb J (2007) Estimating the longevity of limestone drains in treating acid mine drainage containing high concentrations of iron. Appl Geochem 22:2344-2361

Schueck JH, Helfrich DR, Fromell DJ (2004) Limestone upflow pond with siphon discharge design considerations: a simple solution to high volume, high metals AMD discharges. In: Proceedings of the 6th statewide conference on abandoned mine reclamation, Indiana, PA

Seal RR, Shanks WC (2008) Sulfide oxidation: insights from experimental, theoretical, stable isotope, and predictive studies in the field and laboratory. Appl Geochem 23:101-102

Sencindiver JC, Bhumbla DK (1988) Effects of cattails (Typha) on metal removal from mine drainage. In: Mine drainage and surface mine reclamation, vol. 1, info. circular no. 9183. US Bureau of Mines, Pittsburgh, pp 359-366

Sibrell PL, Wildeman T, Frienmuth M, Chambers M, Bless DR (2005) Demonstration of a pulsed limestone bed process for the treatment of acid mine drainage at the Argo Tunnel site, Idaho Springs, Colorado. In: Proceedings of the 22nd ASMR, Breckenridge, CO, pp 1081-1086

Sibrell P, Denholm C, Dunn M (2013) Case study: field trial of a pulsed limestone diversion well. J Amer Society Mining Reclamation 2:160-176

Sikora FJ, Behrends LL, Brodie GA, Bulls MJ (1996) Manganese and trace metal removal in successive anaerobic and aerobic wetlands. In: Proceedings of the American society for surface mining and reclamation, Knoxville, TN, pp 560-579 
Simmons J, Ziemkiewicz PF, Black DC (2002a) Use of steel slag leach beds for the treatment of acid mine drainage. Mine Water Environ 21:91-99

Simmons J, Ziemkiewicz PF, Black DC (2002b) Use of steel slag leach beds for the treatment of acid mine drainage: the McCarty highwall project. In: Proceedings of the 19th ASMR, Lexington, KY, pp 527-538

Skousen J (1991) Anoxic limestone drains for acid mine drainage treatment. Green Lands 21:30-35

Skousen J (1995) Douglas abandoned mine land project: description of an innovative acid mine drainage treatment system. Green Lands 25:29-38

Skousen J, Ziemkiewicz PF (2005) Performance of 116 passive treatment systems for acid mine drainage. In: Proceedings of the 22nd ASMR, Breckenridge, CO, pp 1100-1133

Skousen J, Rose A, Geidel G, Foreman J, Evans R, Hellier W et al (1998) Handbook of technologies for avoidance and remediation of acid mine drainage. National Mine Land Reclamation Center, Morgantown $\mathrm{p} 131$

Smart P, Reisman D, Gusek J, Hathaway E (2008) Case studies - bench scale biochemical reactor results from two sites at the Elizabeth Mine, Vermont. In: Proceedings of the 25th ASMR, Richmond, VA, pp 1017-1038

Sobek AA, Skousen J, Fisher SE (2000) Chemical and physical properties of overburdens and spoils. Chapter 4 reclamation of drastically disturbed lands. Agronomy No. 41. American Society of Agronomy and American Society for Surface Mining and Reclamation, Madison, WI, USA, pp 77-104

Sobolewski A (2010) Benefits of using liquid carbon sources for passive treatment systems. In: Proceedings of the IMWA 2010, Sydney, NS, Canada, pp 279-282

Soucek DJ, Cherry DS, Currie RJ, Latimer HA, Trent GC (2000) Laboratory to field validation in an integrative assessment of an acid mine drainage-impacted watershed. Environ Tox Chem 19:1036-1043

Strosnider WHJ, Llanos Lopez FS, Nairn RW (2011a) Acid mine drainage at Cerro Rico de Potosi II: severe degradation of the Upper Rio Pilcomayo watershed. Environ Earth Sci 64:911-923

Strosnider WHJ, Llanos Lopez FS, Nairn RW (2011b) Acid mine drainage at Cerro Rico de Potosi I: unabated high-strength discharges reflect a five century legacy of mining. Environ Earth Sci 64:899-910

Stumm W, Morgan JJ (1996a) Aquatic chemistry, chemical equilibria and rates in natural waters, 3rd edn. Wiley, New York

Stumm W, Morgan JJ (1996b) Aquatic chemistry, chemical equilibria and rates in natural waters. Oxidation and reduction: equilibrium and microbial reduction, 3rd edn Wiley, New York, pp 359-365

Tebo B, Barger MJR, Clement BG, Dick GJ, Murray K, Parker D, Verity R, Webb SM (2004) Biogenic manganese oxides: properties and mechanisms of formation. Ann Rev Earth Pl Sci 32:287-328

Tebo B, Johnson HA, McCarthy JK, Templeton AS (2005) Geomicrobiology of manganese (II) oxidation. Trends Microbiol 13(9):421-428

Thomas RC, Romanek CS (2002a) Passive treatment of low-pH, ferric iron-dominated acid rock drainage in a vertical flow wetland I: acidity neutralization and alkalinity generation. In: Proceedings of the 19th ASMR, Duluth, MN, pp 723-751

Thomas RC, Romanek CS (2002b) Passive treatment of low-pH, ferric dominated acid rock drainage in a vertical flow wetland-II. Metal removal. In: Proceedings of the 19th ASMR, Duluth, MN, pp 752-775

Thorne B, Pitzer K (2003) Response of fish populations in the Little Sandy watershed. In: Proceedings of the 24th West Virginia surface mine drainage task force symposium, Morgantown, WV

Trumm D, Ball J (2014) Use of sulfate-reducing mussel shell reactors in New Zealand for treatment of acid mine drainage. In:
Proceedings of the 35th West Virginia mine drainage task force symposium, Morgantown, WV

Tsukamoto TK, Killion HA, Miller GC (2004) Column experiments for microbiological treatment of acid mine drainage: low-temperature, low-pH and matrix investigations. Water Res 38:1405-1418

Turner D, McCoy D (1990) Anoxic alkaline drain treatment system, a low cost acid mine drainage treatment alternative. In: Proceedings of the 6th ASMR, Charleston, WV

Uster B, Milke M, O'Sullivan A, Caruso B, Webster-Brown J, Pope J, Trumm D (2015) The use of waste mussel shells in sulfatereducing bioreactors treating acid mine drainage. Mine Water Environ 34:442-454

Venot C, Figueroa L, Brennan RA, Wildeman TR, Reisman D, Sieczkowski M (2008) Comparing chitin and organic substrates on the national tunnel waters in Blackhawk, Colorado, for manganese removal. In: Proceedings of the 25th ASMR, Richmond VA, pp 1352-1366

Vile MA, Weider RK (1993) Alkalinity generation by Fe(III) reduction versus sulfate reduction in wetlands constructed for acid mine drainage treatment. Water Air Soil Poll 69:425-441

Vinci BJ, Schmidt TW (2001) Passive, periodic flushing technology for mine drainage treatment systems. In: Proceedings of the 18th ASMR, Albuquerque, NM, pp 611-625

Watzlaf GR, Nairn RW, Hedin RS, Cooper AR, Borek SL (1992) A laboratory investigation of the effect of $\mathrm{Fe}(\mathrm{II}), \mathrm{Fe}(\mathrm{III})$ and $\mathrm{Al}(\mathrm{III})$ on the performance of anoxic limestone drains. In: Proceedings of the 13th WV surface mine drainage task force symposium, Morgantown, WV

Watzlaf GR, Kleinhenz JW, Odoski JR, Hedin RS (1994) Performance of the Jennings Environmental Center anoxic limestone drain. US Bureau of Mines Report SP 06B-94, Pittsburgh

Watzlaf GR, Schroeder KT, Kairies C (2000a) Long-term performance of alkalinity-producing passive systems for the treatment of mine drainage. In: Proceedings of the 17th ASMR, Tampa, FL, pp 262-274

Watzlaf G, Schroeder KT, Kairies CL (2000b) Long-term performance of anoxic limestone drains. Mine Water Environ 19:98-110

Watzlaf GR, Kairies CL, Schroeder KT, Danehy T, Beam R (2002) Quantitative results from the flushing of four reducing and alkalinity-producing systems. In: Proceedings of the 23rd WV surface mine drainage task force symposium, Morgantown, WV

Watzlaf G, Schroeder KT, Kleinmann RL, Kairies CL, Nairn RW (2004) The passive treatment of coal mine drainage. USDOE/ NETL Report 2004/1202. US DOE National Energy Technology Laboratory, 71(2):136-143

Waybrant KR, Blowes DW, Ptacek CJ (1998) Selection of reactive mixtures for use in permeable reactive walls for treatment of mine drainage. Environ Sci Technol 32:1972-1979

Weaver KR, Lagnese KM, Hedin RS (2004) Technology and design advances in passive treatment system flushing. In: Proceedings of the 21st ASMR and 25th WV surface mine drainage task force symposium, Morgantown, WV, USA

Wei TT, Yu Y, Hu ZQ, Cao YB, Gao Y, Yang YQ, Wang XJ, Wang PJ (2013) Research progress of acid mine drainage treatment technology in China. Appl Mech Mat 409-410:214-220

Wieder RK, Lang GE (1982) Modification of acid mine drainage in a freshwater wetland. In: Proceedings of the symposium on wetlands of the unglaciated Appalachian region. West Virginia University, Morgantown, WV, pp 43-53

Wildeman T, Brodie G, Gusek J (1993) Wetland design for mining operations. BiTech Publisher Ltd, Richmond

Willow MA, Cohen RRH (2003) pH, dissolved oxygen, and adsorption effects on metal removal in anaerobic bioreactors. J Environ Qual 32:1212-1221 
Wilson D (1980) Surface and complexation effects on the rate of $\mathrm{Mn}(\mathrm{II})$ oxidation in natural waters. Geochim Cosmochim Acta 44:1311-1317

Winterbourn MJ, McDiffert WF, Eppley SJ (2000) Aluminum and iron burdens of aquatic biota in New Zealand streams contaminated by acid mine drainage: effect of trophic level. Sci Total Environ 254:45-54

Wolfe N, Hedin RS, Weaver T (2010) Sustained treatment of AMD containing $\mathrm{Al}$ and $\mathrm{Fe}^{3+}$ with limestone aggregate. In: Proceedings of the IMWA symposium, Sydney, NS, Canada, pp 237-241

Yang JE, Kim HJ, Ok YS, Lee JY, Park J (2007) Treatment of abandoned coal mine discharged waters using lime wastes. Geosciences J 11:111-114

Younger PL, Wolkersdorfer C (2004) Mining impacts on the fresh water environment: technical and managerial guidelines for catchment scale management. Mine Water Environ 23:s2-s80

Younger PL, Banwart SA, Hedin RS (2002) Mine water: hydrology, pollution, remediation. Kluwer Academic Publication, Boston, $\mathrm{p}$ 464

Zachara JM, Cowan CE, Resch CT (1991) Sorption of divalent metals on calcite. Geochim Cosmochim Acta 55:1549-1562

Zagury GJ, Kulnieks VI, Neculita CM (2006) Characterization and reactivity assessment of organic substrates for sulphate-reducing bacteria in acid mine drainage treatment. Chemosphere 64:944-954

Zaluski MH, Trudnowski JM, Harrington-Baker MA, Bless DR (2003) Post-mortem findings on the performance of engineered SRB field-bioreactors for acid mine drainage control. In: Proceedings of the 6th ICARD, Cairns, Australia, pp 845-853

Zamzow KL, Tsukamoto TK, Miller GC (2006) Waste from biodiesel manufacturing as an inexpensive carbon source for bioreactors treating acid mine drainage. Mine Water Environ $25: 163-170$
Ziemkiewicz PF (1998) Steel slag: applications for AMD control. In: Proceedings of the 1998 conference on hazardous waste research, Snowbird, UT, pp 44-62

Ziemkiewicz PF, Brant D (1997) The casselman river restoration project. In: Proceedings of the 18th WV surface mine drainage task force symposium, Morgantown, WV, USA

Ziemkiewicz PF, Skousen J (1998) The use of steel slag in acid mine drainage treatment and control. In: Proceedings of the 19th WV surface mine drainage task force symposium, Morgantown, WV, USA

Ziemkiewicz PF, Skousen J, Lovett R (1994) Open limestone channels for treating acid mine drainage: a new look at an old idea. Green Lands 24:36-41

Ziemkiewicz PF, Skousen J, Brant D, Sterner P, Lovett R (1997) Acid mine drainage treatment with armored limestone in open limestone channels. J Environ Qual 26:560-569

Ziemkiewicz PF, Skousen J, Simmons JS (2002) Long-term performance of passive acid mine drainage treatment systems. In: Proceedings of the 23rd WV surface mine drainage task force symposium, Morgantown, WV

Ziemkiewicz P, Skousen J, Simmons JS (2003) Long-term performance of passive acid mine drainage treatment systems. Mine Water Environ 22:118-129

Zipper CE, Skousen J (2010) Influent water quality affects performance of passive treatment systems for acid mine drainage. Mine Water Environ 29:135-143

Zurbuch PE (1996) Early results from calcium carbonate neutralization of two West Virginia rivers acidified by mine drainage. In: Proceedings of the 17th WV surface mine drainage task force symposium. Morgantown, WV

Blowes DW, Ptacek CJ, Jambor JL, Weisner CG, Paktunc D, Gould WD, Johnson DB (2003) The geochemistry of acid mine drainage. In: Lollar BS (ed) Treatise on geochemistry, vol 9. Elsevier, Amsterdam, pp 149-204 